\title{
ICHTHYOFAUNA OF THE ITIMBIRI, ARUWIMI, AND LINDI/TSHOPO RIVERS (CONGO BASIN): DIVERSITY AND DISTRIBUTION PATTERNS
}

\author{
Eva DECRU ${ }^{1,2}$, Emmanuel VREVEN ${ }^{1,2}$, Célestin DANADU ${ }^{3,4}$, Albert WALANGA $^{4}$, \\ Taylor $\mathrm{MAMBO}^{4}$, and Jos SNOEKS ${ }^{1,2}$ \\ ${ }^{1}$ Royal Museum for Central Africa, Section Vertebrates, Ichthyology, Tervuren, Belgium \\ ${ }^{2}$ KU Leuven, Laboratory of Biodiversity and Evolutionary Genomics, Leuven, Belgium \\ ${ }^{3}$ Faculté des Sciences, Université de Kisangani, Kisangani, République Démocratique du Congo \\ ${ }^{4}$ Département d'Ecologie et Biodiversité des Ressources Aquatiques, Centre de Surveillance de la \\ Biodiversité, Université de Kisangani, Kisangani, République Démocratique du Congo
}

\begin{abstract}
Decru E., Vreven E., Danadu C., Walanga A., Mambo T., Snoeks J. 2017. Ichthyofauna of the Itimbiri, Aruwimi, and Lindi/Tshopo rivers (Congo basin): Diversity and distribution patterns. Acta Ichthyol. Piscat. 47 (3): 225-247.
\end{abstract}

Background. Although the Congo basin is the second largest river basin in the world and it has been considered a biodiversity hotspot for fish, still many parts of this basin remain poorly studied. In this study, we examined the poorly known ichthyofauna of three major north-eastern tributaries of the Congo basin (Itimbiri, Aruwimi and Lindi/Tshopo). A checklist of the ichthyofauna is provided and two synonymies are presented. As such, it contributes to unraveling the poorly known fish diversity in the whole Congo basin. An improved knowledge of the ichthyofauna is a sound baseline for further studies and conservation

Material and methods. Fish specimens from five recent expeditions have been identified, and the older collection material from the study area, housed at the Royal Museum for Central Africa and other institutions has been checked and re-identified when necessary.

Results. In total, 320 species were recorded, 232 of which from the Itimbiri, 246 from the Aruwimi, and 187 from the Lindi/Tshopo, with the Mormyridae being the most dominant family in all three basins. Micralestes sardina Poll, 1938 is relegated to synonymy with Micralestes humilis Boulenger, 1899, and Enteromius trinotatus (Fowler, 1936) is designated as a replacement name for Enteromius tetraspilus (Pfeffer, 1896). Within the Aruwimi, a clear difference in species richness and composition is apparent between the headwaters (Ituri/Epulu) and the lower reaches near the Congo main stream. The headwaters are characterised by low species richness, with the Cyprinidae being the most dominant family, while the lower reaches are more species rich, with mormyrid species being the most dominant. The presence of two waterfalls on the Ituri/Epulu has a noticeable impact on the fish distribution. Finally, the hypothesis that an ancient connection between the north-eastern part of the Congo basin and the region of the Albertine Rift is still reflected in their present ichthyofauna is not confirmed.

Conclusions. This study provides a first checklist of the ichthyofauna in the north-eastern tributaries of the Congo basin, and illustrates the influence of physical barriers on fish diversity and distribution.

Keywords: checklist, north-eastern Congo, fish diversity, Albertine Rift, waterfalls

\section{INTRODUCTION}

With a catchment area of about $3700000 \mathrm{~km}^{2}$, the Congo is the second largest river basin in the world, only preceded by the Amazon (Runge 2007, Snoeks et al. 2011). It is known for its very high fish diversity with about 986 valid species, excluding the basin of Lake Tanganyika (Froese and Pauly 2017), and is a recognized hotspot for fish diversity (Snoeks et al. 2011). Additionally, it has a high degree of endemism estimated at about $75 \%$, even when excluding the Lake Tanganyika endemics (Snoeks et al. 
2011). Nevertheless, large parts of the Congo basin remain unexplored and/or poorly studied. The last decade, surveys and studies have been undertaken on several parts of the Congo basin to improve our knowledge of the ichthyofauna (e.g., Hanssens 2009, Lowenstein et al. 2011, Stiassny et al. 2011, Monsembula Iyaba et al. 2013, Van Steenberge et al. 2014, Ibala-Zamba unpublished*, Wamuini Lunkayilakio unpublished $^{* *}$ ). These studies have led to a significant increase in the number of documented species in the explored areas, and the description of several new species.

The presently reported study focussed on the ichthyofauna of the three most important north-eastern tributaries of the Congo River downstream of the Wagenia Falls, that are not part of the Ubangi system: the Itimbiri, Aruwimi, and Lindi/Tshopo rivers (Fig. 1). These tributaries are the three major right-bank systems of what is considered the Cuvette Centrale (Central Basin) according to Abell et al. (2008). The Cuvette Centrale covers the largest zone of lowland rainforest in Africa, is completely flat, and its major habitat type is 'moist forest rivers' (Thieme et al. 2005). The Aruwimi has the largest surface area of the three. Its upper part, up to the confluence with the Nepoko, is called the Ituri, with the Epulu River as its most important right bank affluent. The Ituri contains several stretches of rapids and waterfalls that might influence fish species composition (Thieme et al. 2005). One of those, the Arabia Falls, is located just upstream of the confluence of the Epulu with the Ituri, and as such isolates the Epulu from the rest of the Ituri. These upper parts of the Aruwimi are located in the dense Ituri tropical rainforest, which is known to have an organic-rich nature (Koenig 2008). This area is situated relatively high, up to $1350 \mathrm{~m}$ on the highest hills near the Epulu, and the bottom of the rivers are here mainly rocky (Katuala et al. 2005).
The easternmost parts of these north-eastern affluents are located close to the Nile system, but are separated from it by a series of mountain chains in the East African Rift System (EARS). Before the tectonic uplifting in the area during the Late Miocene/Pliocene (ca. 7.5-2.5 MYA), a paleo-lake Obweruka existed in the Albertine rift, roughly where now lakes Albert and Edward (currently draining into the Nile system) are situated, and which was connected with the proto-Aruwimi of the Congo basin (Van Damme and Pickford 1999, Van Damme and Van Bocxlaer 2009). This ancient connection between the Congo and the Northern Albertine Rift Lakes may still be reflected in the present ichthyofauna. Although ichthyofaunal exchange between the Congo and Nile systems has been studied via other pathways such as the Lualaba (Cahen 1954, Poll 1963, Banister and Baily 1979, Beadle 1981), such an exchange via the Albertine rift region has never been investigated for the Ituri region. Our study provides:

- A review of the diversity of the ichthyofauna of some poorly explored north-eastern affluents of the Congo basin; and

- An examination of ichthyofaunal similarities between the Congo and the area of the Northern Albertine Rift in the Ituri region.

\section{MATERIAL AND METHODS}

The following abbreviations are used through the text: DRC = Democratic Republic of the Congo, $\mathrm{HL}=$ head length, SL = standard length. Institutional abbreviations for collection numbers follow Sabaj Perez (2014); hence, the conventional abbreviation MRAC is used for collection numbers of the Royal Museum for Central Africa (RMCA), Tervuren, and BMNH for collection numbers of the Natural History Museum, London (NHM).

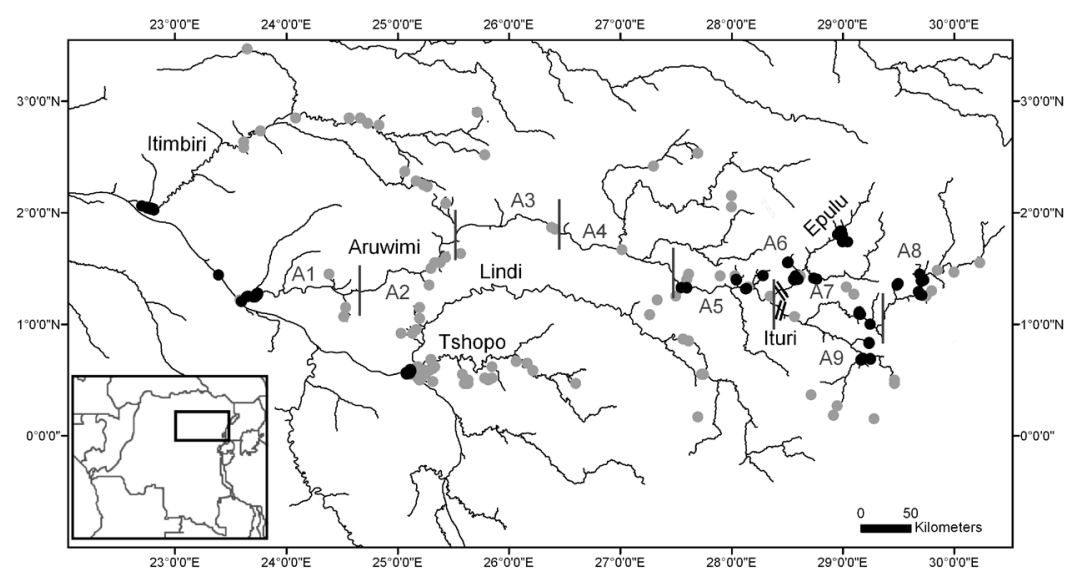

Fig. 1. Map of the area with the north-eastern tributaries of the Congo basin studied; sampling regions of the recent expeditions executed between 2009 and 2014 are indicated (•), as well as the localities of older collection material from the Royal Museum for Central Africa (•), and the $130 \mathrm{~km}$ segments within the Aruwimi basin (see text); the waterfalls on the Epulu and the Ituri are indicated with two parallel lines; inset map shows the position of the explored region in the Democratic Republic of the Congo

* Ibala-Zamba A. 2010. Faune des poissons des rivières Luki et Léfini (bassin du Congo): diversité et écologie. PhD thesis, KU Leuven, Leuven, Belgium.

** Wamuini Lunkayilakio S. 2010. Ichtyofaune de l'Inkisi (Bas-Congo/RDC): Diversité et écologie. PhD thesis, Université de Liège, Liège, Belgium. 
Fish specimens from five recent expeditions have been identified (RMCA collection numbers given in brackets):

- Congo 2009 (2009-24);

- Congo 2010 (2010-17);

- Okapi Wildlife Reserve (OWR) 2009 (2009-29);

- Ituri 2011 (2011-11);

- Lindi 2014 (2014-17).

The above-mentioned expeditions have been carried out in accordance with the country's regulations.

Older collection material from the study area, curated at the Royal Museum for Central Africa (RMCA), has been checked and re-identified when necessary. The data was complemented with collection records from other institutions: the Natural History Museum, London (NHM), Musée National d'Histoire Naturelle, Paris (MNHN), Cornell University, Ithaca (CU), and the American Museum of Natural History, New York $(\mathrm{AMNH})$; identifications were checked when necessary. Identifications were mainly based on revisions of families and genera, and the original species descriptions. For three groups, identifications were performed by other specialists: Nothobranchiidae and Poeciliidae by Jouke Van der Zee and Rainer Sonnenberg, and Nannocharax by Fernando Jerep (MCT-PUCRS). For species numbers and further analyses, only records for which the identification was checked, have been included. In a few cases not all data was available; the voucher specimens could not be traced, were too damaged to allow proper identification, or the collection locality was judged unreliable. When species were only known from the study region from these dubious records, they were considered as possible incorrect species records. They are listed as such in Table 1 (see below) with a question mark, but were excluded from the analyses.
To examine possible ichthyofaunal similarities between the study region and the Albertine Rift region, our compiled species list was compared with museum records (RMCA and other institutions mentioned above) from the region of the Albertine Rift. The identifications of records of shared species in the Congo and Albertine Rift region were then verified.

As both the headwaters and the lower reaches of the Aruwimi basin have been intensively sampled, we had the opportunity to further explore the distribution patterns within this basin and assess the possible influence of rapids and waterfalls in the headwaters. For this, the Aruwimi has been divided into different sections, labelled A1, A2, A3, A4, A5, A6, A7, A8, and A9. The length of the Epulu River, from the most upstream sampling site downstream to the Arabia Falls near its mouth, comprising about 130 $\mathrm{km}$, has been taken as the unit of reference. The Aruwimi basin has thus been divided into sections of about 130 $\mathrm{km}$, with A1 being closest to the main stream, and A9 the most upstream section (Fig. 1). A5 up to A9, the upstream sections of the Aruwimi basin, are called the Ituri River. A5 is the section downstream of the confluence of the Epulu with the Ituri, A6 is the Epulu itself, and A7-A9 are sections of the Ituri River upstream of this confluence.

In order to visualize the degree of (dis)similarities between the different sections of the Aruwimi basin, a correspondence analysis on the presence/absence matrix (Manly 1994) of the ichthyofauna in the Aruwimi has been carried out. The main goal of this analysis was to transform a table of numerical information $(0 / 1$ in our case) into a graphical display, in which each column (representing the river sections) is depicted as a point. River sections with a more similar species composition are situated more closely to each other on a two-dimensional graph.

Table 1

List of fish species recorded from the three north-eastern tributaries of the Congo basin studied; in addition, the Ituri River (Aruwimi headwaters) is indicated separately

\begin{tabular}{|c|c|c|c|c|}
\hline Species & Itimbiri & Aruwimi & $\begin{array}{l}\text { Lindi/ } \\
\text { Tshopo }\end{array}$ & Ituri \\
\hline \multicolumn{5}{|l|}{ POLYPTERIDAE (5) } \\
\hline Polypterus delhezi Boulenger, 1899 & + & - & - & - \\
\hline Polypterus ornatipinnis Boulenger, 1902 & + & + & + & + \\
\hline Polypterus polli Gosse, 1988 & + & - & - & - \\
\hline Polypterus retropinnis Vaillant, 1899 & + & + & - & - \\
\hline Polypterus weeksii Boulenger, 1898 & + & - & - & - \\
\hline \multicolumn{5}{|l|}{ PANTODONTIDAE (1) } \\
\hline Pantodon bucholzi Peters, 1877 & + & + & - & - \\
\hline \multicolumn{5}{|l|}{ NOTOPTERIDAE (2) } \\
\hline Papyrocranus congoensis (Günther, 1868) & + & + & - & - \\
\hline Xenomystus nigri (Günther, 1868) & + & + & + & - \\
\hline \multicolumn{5}{|l|}{ MORMYRIDAE (59) } \\
\hline Campylomormyrus alces (Boulenger, 1920) & - & + & - & + \\
\hline Campylomormyrus curvirostris (Boulenger, 1898) & - & + & - & + \\
\hline Campylomormyrus elephas (Boulenger, 1898) & - & + & + & + \\
\hline
\end{tabular}


Table 1 cont.

\begin{tabular}{|c|c|c|c|c|}
\hline Species & Itimbiri & Aruwimi & $\begin{array}{l}\text { Lindi// } \\
\text { Tshopo }\end{array}$ & Ituri \\
\hline Campylomormyrus mirus (Boulenger, 1898) & - & + & + & + \\
\hline Campylomormyrus numenius (Boulenger, 1898) & + & + & + & + \\
\hline Campylomormyrus rhynchophorus (Boulenger, 1898) & + & + & + & + \\
\hline Campylomormyrus tamandua (Günther, 1864) & + & + & + & + \\
\hline Cyphomyrus discorhynchus (Peters, 1852) & - & - & + & - \\
\hline Cyphomyrus psittacus (Boulenger, 1897) & + & + & + & + \\
\hline Cyphomyrus wilverthi (Boulenger, 1898) & - & + & - & - \\
\hline Genyomyrus donnyi Boulenger, 1898 & + & + & - & + \\
\hline Gnathonemus echidnorhynchus Pellegrin, 1924 & + & + & - & - \\
\hline Gnathonemus petersii (Günther, 1862) & + & + & + & + \\
\hline Hippopotamyrus weeksii (Boulenger, 1902) & + & + & - & + \\
\hline Marcusenius angolensis (Boulenger, 1905) & - & + & - & - \\
\hline Marcusenius greshoffi (Schilthuis, 1891) & + & + & + & + \\
\hline Marcusenius intermedius Pellegrin, 1924 & + & - & - & - \\
\hline Marcusenius kutuensis (Boulenger, 1899) & + & + & - & - \\
\hline Marcusenius leopoldianus (Boulenger, 1899) & + & - & - & - \\
\hline Marcusenius monteiri (Günther, 1873) & + & + & + & + \\
\hline Marcusenius moorii (Günther, 1867) & + & - & + & - \\
\hline Marcusenius schilthuisiae (Boulenger, 1899) & + & + & + & - \\
\hline Marcusenius sp. 'ruiki' & + & - & - & - \\
\hline Marcusenius stanleyanus (Boulenger, 1897) & + & + & + & + \\
\hline Mormyrops anguilloides (Linnaeus, 1758) & + & + & + & + \\
\hline Mormyrops attenuatus Boulenger, 1898 & + & + & + & + \\
\hline Mormyrops boulengeri (Pellegrin, 1900) & + & - & - & - \\
\hline Mormyrops furcidens Pellegrin, 1900 & + & - & - & - \\
\hline Mormyrops intermedius Vinciguerra, 1928 & $?$ & - & - & - \\
\hline Mormyrops mariae (Schilthuis, 1891) & - & + & + & + \\
\hline Mormyrops masuianus Boulenger, 1898 & + & + & - & + \\
\hline Mormyrops nigricans Boulenger, 1899 & + & + & + & - \\
\hline Mormyrops sirenoides Boulenger, 1898 & + & + & - & + \\
\hline Mormyrops zanclirostris (Günther, 1867) & + & - & - & - \\
\hline Mormyrus caballus Boulenger, 1898 & - & + & + & + \\
\hline Mormyrus ovis Boulenger, 1898 & - & + & + & + \\
\hline Mormyrus rume Valenciennes, 1847 & - & + & - & + \\
\hline Myomyrus macrodon Boulenger, 1898 & - & $?$ & - & $?$ \\
\hline Myomyrus macrops Boulenger, 1914 & + & + & + & + \\
\hline Myomyrus pharao Poll et Taverne, 1967 & - & $?$ & - & $?$ \\
\hline Paramormyrops kingsleyae (Günther, 1896) & - & + & + & + \\
\hline Petrocephalus binotatus Pellegrin, 1924 & + & - & + & - \\
\hline Petrocephalus christyi Boulenger, 1920 & + & + & + & + \\
\hline Petrocephalus grandoculis Boulenger, 1920 & + & + & + & + \\
\hline Petrocephalus microphthalmus Pellegrin, 1909 & + & + & + & + \\
\hline Petrocephalus sauvagii (Boulenger, 1887) & + & + & + & + \\
\hline Petrocephalus schoutedeni Poll, 1954 & + & + & + & - \\
\hline Petrocephalus sp. 'simus Congo' & - & + & - & $?$ \\
\hline Pollimyrus adspersus (Günther, 1866) & - & + & + & - \\
\hline Pollimyrus nigripinnis (Boulenger, 1899) & + & + & + & + \\
\hline Pollimyrus osborni (Valenciennes, 1847) & + & + & + & + \\
\hline Pollimyrus plagiostoma (Boulenger, 1898) & + & + & + & + \\
\hline Pollimyrus pulverulentus (Boulenger, 1899) & + & - & - & - \\
\hline Pollimyrus tumifrons Boulenger, 1902 & - & + & + & + \\
\hline
\end{tabular}

Table continues on next page. 
Table 1 cont.

\begin{tabular}{|c|c|c|c|c|}
\hline Species & Itimbiri & Aruwimi & $\begin{array}{l}\text { Lindi/ } \\
\text { Tshopo }\end{array}$ & Ituri \\
\hline Stomatorhinus corneti Boulenger, 1899 & + & - & - & - \\
\hline Stomatorhinus fuliginosus Poll, 1941 & + & + & + & - \\
\hline Stomatorhinus humilior Boulenger, 1899 & + & + & + & - \\
\hline Stomatorhinus kununguensis Poll, 1945 & + & + & + & - \\
\hline Stomatorhinus patrizii Vinciguerra, 1928 & + & - & + & - \\
\hline \multicolumn{5}{|l|}{ CLUPEIDAE (6) } \\
\hline Microthrissa congica (Regan, 1917) & + & + & + & + \\
\hline Microthrissa royauxi Boulenger, 1902 & + & + & + & + \\
\hline Odaxothrissa losera Boulenger, 1899 & - & + & + & - \\
\hline Potamothrissa acutirostris (Boulenger, 1899) & + & + & + & + \\
\hline Potamothrissa obtusirostris (Boulenger, 1909) & + & + & + & + \\
\hline Potamothrissa whiteheadi Poll, 1974 & - & - & + & - \\
\hline \multicolumn{5}{|l|}{ KNERIIDAE (2) } \\
\hline Grasseichthys sp. 'Congo' & - & - & ? & - \\
\hline Parakneria cameronensis (Boulenger, 1909) & + & + & - & + \\
\hline \multicolumn{5}{|l|}{ CYPRINIDAE (45) } \\
\hline Enteromius amanpoae (Lambert, 1961) & - & - & + & - \\
\hline Enteromius atromaculatus (Nichols et Griscom, 1917) & + & + & + & $?$ \\
\hline Enteromius brazzai (Pellegrin, 1901) & + & - & + & - \\
\hline Enteromius candens (Nichols et Griscom, 1917) & + & - & + & - \\
\hline Enteromius cf. brazzai (Pellegrin, 1901) & - & $\mathrm{E}$ & - & $\mathrm{E}$ \\
\hline Enteromius cf. apleurogramma (Boulenger, 1911) & - & + & - & + \\
\hline Enteromius holotaenia (Boulenger, 1904) & + & $?$ & + & - \\
\hline Enteromius humeralis (Boulenger, 1902) & + & + & - & + \\
\hline Enteromius jae (Boulenger, 1903) & + & + & + & + \\
\hline Enteromius miolepis (Boulenger, 1902) & + & + & + & + \\
\hline Enteromius sp. ' $10 \mathrm{cps'}$ & - & + & + & + \\
\hline Enteromius trinotatus (Fowler, 1936) & - & $\mathrm{E}$ & - & $\mathrm{E}$ \\
\hline Chelaethiops congicus (Nichols et Griscom, 1917) & + & + & + & + \\
\hline Chelaethiops elongatus Boulenger, 1899 & + & + & + & + \\
\hline Clypeobarbus congicus (Boulenger, 1899) & + & - & - & - \\
\hline Clypeobarbus pleuropholis (Boulenger, 1899) & + & + & + & + \\
\hline Garra dembeensis (Rüppel, 1835) & - & + & + & + \\
\hline Labeo altivelis Peters, 1852 & + & + & + & + \\
\hline Labeo annectens Boulenger, 1903 & + & + & - & + \\
\hline Labeo barbatus Boulenger, 1898 & - & + & - & + \\
\hline Labeo cyclopinnis Nichols et Griscom, 1917 & + & - & - & - \\
\hline Labeo chariensis Pellegrin, 1904 & + & + & - & + \\
\hline Labeo cyclorhynchus Boulenger, 1899 & - & + & + & + \\
\hline Labeo greenii Boulenger, 1902 & - & + & + & + \\
\hline Labeo lineatus Boulenger, 1898 & + & + & + & - \\
\hline Labeo longipinnis Boulenger, 1898 & + & + & + & + \\
\hline Labeo lukulae Boulenger, 1902 & - & + & - & + \\
\hline Labeo macrostomus Boulenger, 1898 & - & + & - & - \\
\hline Labeo nasus Boulenger, 1899 & - & + & - & + \\
\hline Labeo parvus Boulenger, 1902 & + & + & + & + \\
\hline Labeo reidi Tshibwabwa, 1997 & - & - & + & - \\
\hline Labeobarbus caudovittatus (Boulenger, 1902) & + & + & + & + \\
\hline Labeobarbus humphri (Banister, 1976) & - & $\mathrm{E}$ & - & $\mathrm{E}$ \\
\hline Labeobarbus iturii (Holly, 1929) & - & $?(\mathrm{E})$ & - & $?(\mathrm{E})$ \\
\hline Labeobarbus longidorsalis Pellegrin, 1935 & - & + & - & + \\
\hline Labeobarbus macroceps (Fowler, 1936) & - & $\mathrm{E}$ & - & $\mathrm{E}$ \\
\hline
\end{tabular}


Table 1 cont.

\begin{tabular}{|c|c|c|c|c|}
\hline Species & Itimbiri & Aruwimi & $\begin{array}{l}\text { Lindi/ } \\
\text { Tshopo }\end{array}$ & Ituri \\
\hline Labeobarbus mawambiensis (Steindachner, 1911) & - & + & - & + \\
\hline Labeobarbus mirabilis (Pappenheim et Boulenger, 1914) & - & $\mathrm{E}$ & - & $\mathrm{E}$ \\
\hline Leptocypris lujae (Boulenger, 1909) & - & + & + & + \\
\hline Leptocypris modestus Boulenger, 1900 & - & + & + & + \\
\hline Leptocypris weeksii (Boulenger, 1899) & + & - & + & - \\
\hline Leptocypris weynsii (Boulenger, 1899) & - & + & + & + \\
\hline Opsaridium ubangense (Pellegrin, 1901) & + & + & + & + \\
\hline Raiamas christyi (Boulenger, 1920) & + & + & - & + \\
\hline Raiamas salmolucius (Nichols et Griscom, 1917) & + & + & + & + \\
\hline \multicolumn{5}{|l|}{ DISTICHODONTIDAE (35) } \\
\hline Belonophago hutsebouti Giltay, 1929 & + & - & + & - \\
\hline Distichodus affinis Günther, 1873 & + & + & + & + \\
\hline Distichodus antonii Schilthuis, 1891 & + & + & + & + \\
\hline Distichodus atroventralis Boulenger, 1898 & + & + & - & + \\
\hline Distichodus decemmaculatus Pellegrin, 1926 & + & - & - & - \\
\hline Distichodus fasciolatus Boulenger, 1898 & + & + & + & + \\
\hline Distichodus langii Nichols et Griscom, 1917 & - & + & - & + \\
\hline Distichodus lusosso Schilthuis, 1891 & + & + & + & + \\
\hline Distichodus maculatus Boulenger, 1898 & - & + & + & + \\
\hline Distichodus noboli Boulenger, 1899 & + & + & - & - \\
\hline Distichodus sexfasciatus Boulenger, 1897 & + & + & + & + \\
\hline Distichodus teugelsi Mamonekene et Vreven, 2008 & + & + & - & - \\
\hline Eugnathichthys eetveldii Boulenger, 1898 & + & + & + & + \\
\hline Eugnathichthys macroterolepis Boulenger, 1899 & + & + & + & + \\
\hline Eugnathichthys virgatus Stiassny, Denton et Monsembula Iyaba, 2013 & + & + & - & - \\
\hline Hemigrammocharax uniocellatus (Pellegrin, 1926) & + & - & - & - \\
\hline Hemistichodus mesmaekersi Poll, 1959 & + & - & + & - \\
\hline Ichthyborus besse congolensis Giltay, 1930 & - & - & + & - \\
\hline Ichthyoborus ornatus (Boulenger, 1899) & + & - & + & - \\
\hline Mesoborus crocodilus Pellegrin, 1900 & + & + & + & + \\
\hline Microstomatichthyoborus bashforddeani Nichols et Griscom, 1917 & + & - & - & - \\
\hline Nannocharax brevis Boulenger, 1902 & + & + & + & + \\
\hline Nannocharax elongatus Boulenger, 1900 & + & + & + & + \\
\hline Nannocharax gracilis Poll, 1939 & - & - & $?$ & - \\
\hline Nannocharax macropterus Pellegrin, 1926 & + & - & - & - \\
\hline Nannocharax procatopus Boulenger, 1920 & + & + & + & + \\
\hline Nannocharax pteron Fowler, 1936 & + & - & - & - \\
\hline Nannocharax schoutedeni Poll, 1939 & + & - & - & - \\
\hline Nannocharax taenia Boulenger, 1902 & + & + & - & - \\
\hline Neolebias philippei Poll et Gosse, 1963 & + & - & + & - \\
\hline Neolebias trewavasae Poll et Gosse, 1963 & - & - & + & - \\
\hline Neolebias trilineatus Boulenger, 1899 & + & + & - & - \\
\hline Phago boulengeri Schilthuis, 1891 & + & + & + & - \\
\hline Phago intermedius Boulenger, 1899 & + & + & + & - \\
\hline Xenocharax spilurus Günther, 1867 & + & + & - & - \\
\hline \multicolumn{5}{|l|}{ CITHARINIDAE (3) } \\
\hline Citharinus congicus Boulenger, 1897 & - & - & + & - \\
\hline Citharinus gibbosus Boulenger, 1899 & + & + & + & + \\
\hline Citharinus macrolepis Boulenger, 1899 & + & + & + & - \\
\hline \multicolumn{5}{|l|}{ HEPSETIDAE (1) } \\
\hline Hepsetus microlepis (Boulenger, 1901) & + & + & - & $?$ \\
\hline
\end{tabular}

Table continues on next page. 
Table 1 cont.

\begin{tabular}{|c|c|c|c|c|}
\hline Species & Itimbiri & Aruwimi & $\begin{array}{l}\text { Lindi/ } \\
\text { Tshopo }\end{array}$ & Ituri \\
\hline \multicolumn{5}{|l|}{ ALESTIDAE (29) } \\
\hline Alestes liebrechtsii Boulenger, 1898 & + & + & + & $?$ \\
\hline Alestes macrophthalmus Günther, 1867 & + & + & + & + \\
\hline Alestopetersius caudalis (Boulenger, 1899) & + & + & + & + \\
\hline Alestopetersius compressus (Poll et Gosse, 1963) & + & + & + & - \\
\hline Bathyaethiops caudomaculatus (Pellegrin, 1925) & + & - & - & - \\
\hline Brachypetersius altus (Boulenger, 1899) & + & + & + & - \\
\hline Brachypetersius pseudonummifer Poll, 1967 & - & + & + & + \\
\hline Brycinus bimaculatus (Boulenger, 1899) & + & + & - & - \\
\hline Brycinus epuluensis (Decru et al., 2016) & - & $\mathrm{E}$ & - & $\mathrm{E}$ \\
\hline Brycinus grandisquamis (Boulenger, 1899) & + & + & + & + \\
\hline Brycinus imberi (Boulenger, 1899) & + & + & + & + \\
\hline Brycinus kingsleyae (Günther, 1896) & - & + & + & + \\
\hline Brycinus poptae (Pellegrin, 1906) & + & + & + & - \\
\hline Brycinus sp. 'hepsetus' & + & + & + & + \\
\hline Bryconaethiops boulengeri Pellegrin, 1900 & + & + & + & + \\
\hline Bryconaethiops macrops Boulenger, 1920 & + & + & + & + \\
\hline Bryconaethiops microstoma Günther, 1873 & + & + & + & + \\
\hline Hydrocynus goliath Boulenger, 1898 & - & + & + & + \\
\hline Hydrocynus vittatus Castelnau, 1861 & + & + & + & + \\
\hline Micralestes acutidens (Peters, 1852) & + & + & + & + \\
\hline Micralestes holargyreus (Günther 1873) & - & $?$ & - & $?$ \\
\hline Micralestes humilis Boulenger, 1899 & + & + & + & + \\
\hline Micralestes lualabae Poll, 1967 & + & + & + & + \\
\hline Micralestes stormsi Boulenger, 1902 & + & + & + & + \\
\hline Phenacogrammus aurantiacus (Pellegrin, 1930) & + & - & + & - \\
\hline Phenacogrammus deheyni Poll, 1945 & - & + & - & - \\
\hline Phenacogrammus interruptus (Boulenger, 1899) & + & + & + & - \\
\hline Phenacogrammus polli Lambert, 1961 & - & - & + & - \\
\hline Rhabdalestes yokai Ibala Zamba et Vreven, 2008 & + & - & - & - \\
\hline \multicolumn{5}{|l|}{ AMPHILIIDAE (9) } \\
\hline Amphilius brevis Boulenger, 1902 & + & + & + & - \\
\hline Amphilius zairiensis Skelton, 1986 & - & + & - & + \\
\hline Belonoglanis tenuis Boulenger, 1902 & + & + & - & - \\
\hline Congoglanis alula Nichols et Griscom, 1917 & + & + & - & + \\
\hline Phractura lindica Boulenger, 1902 & - & - & + & - \\
\hline Phractura tenuicauda (Boulenger, 1902) & + & - & + & - \\
\hline Leptoglanis xenognathus Boulenger, 1902 & - & + & - & - \\
\hline Trachyglanis ineac (Poll, 1954) & + & - & - & - \\
\hline Zaireichthys mandevillei (Poll, 1959) & - & - & + & - \\
\hline \multicolumn{5}{|l|}{ MOCHOKIDAE (24) } \\
\hline Acanthocleithron chapini Nichols et Griscom, 1917 & - & + & - & + \\
\hline Atopochilus christyi Boulenger, 1920 & + & + & + & + \\
\hline Chiloglanis micropogon Poll, 1952 & - & + & - & + \\
\hline Euchilichthys dybowskii (Vaillant, 1892) & - & + & - & + \\
\hline Euchilichthys guentheri (Schilthuis, 1891) & - & $?$ & - & $?$ \\
\hline Euchilichthys royauxi Boulenger, 1902 & - & + & + & + \\
\hline Microsynodontis christyi Boulenger 1920 & + & + & - & - \\
\hline Synodontis acanthomias Boulenger, 1899 & + & + & + & + \\
\hline Synodontis alberti Schilthuis, 1891 & + & + & + & - \\
\hline Synodontis angelicus Schilthuis, 1891 & + & + & - & - \\
\hline Synodontis centralis Poll, 1971 & + & + & - & - \\
\hline
\end{tabular}


Table 1 cont.

\begin{tabular}{|c|c|c|c|c|}
\hline Species & Itimbiri & Aruwimi & $\begin{array}{l}\text { Lindi/ } \\
\text { Tshopo }\end{array}$ & Ituri \\
\hline Synodontis congicus Poll, 1971 & + & + & - & - \\
\hline Synodontis contractus Vinciguerra, 1928 & + & + & - & - \\
\hline Synodontis decorus Boulenger, 1899 & + & + & + & + \\
\hline Synodontis depauwi Boulenger, 1899 & - & $?$ & - & - \\
\hline Synodontis flavitaeniatus Boulenger, 1919 & + & - & - & - \\
\hline Synodontis greshoffi Schilthuis, 1891 & + & + & + & + \\
\hline Synodontis iturii Steindachner, 1911 & - & $\mathrm{E}$ & - & $\mathrm{E}$ \\
\hline Synodontis nigriventris David, 1936 & + & + & - & - \\
\hline Synotontis notatus Vaillant, 1893 & + & - & - & - \\
\hline Synodontis nummifer Boulenger, 1899 & + & + & + & - \\
\hline Synodontis pleurops Boulenger, 1897 & + & + & + & + \\
\hline Synodontis schoutedeni David, 1936 & + & - & - & - \\
\hline Synodontis smiti Boulenger, 1902 & - & + & - & + \\
\hline \multicolumn{5}{|l|}{ MALAPTERURIDAE (6) } \\
\hline Malapterurus electricus (Gmelin, 1789) & $?$ & $?$ & - & - \\
\hline Malapterurus melanochir Norris, 2002 & + & + & - & - \\
\hline Malapterurus microstoma Poll et Gosse, 1969 & + & + & + & $?$ \\
\hline Malapterurus monsembeensis Roberts, 2000 & + & + & + & + \\
\hline Paradoxoglanis cryptus Norris, 2002 & $\mathrm{E}$ & - & - & - \\
\hline Paradoxoglanis parvus Norris, 2002 & + & - & - & - \\
\hline \multicolumn{5}{|l|}{ CLARIIDAE (19) } \\
\hline Channallabes apus (Günther, 1873) & + & + & + & - \\
\hline Clariallabes laticeps (Steindachner, 1911) & - & + & + & - \\
\hline Clariallabes melas (Boulenger, 1887) & - & + & + & - \\
\hline Clariallabes simeonsi Poll 1941 & $\mathrm{E}$ & - & - & - \\
\hline Clariallabes uelensis (Poll, 1941) & + & - & - & - \\
\hline Clariallabes variabilis Pellegrin, 1926 & + & + & + & - \\
\hline Clarias angolensis Steindachner, 1866 & + & + & + & + \\
\hline Clarias buthupogon Sauvage, 1879 & + & + & + & + \\
\hline Clarias camerunensis Lönnberg, 1895 & + & + & + & + \\
\hline Clarias dumerilii Steindachner, 1866 & + & + & + & + \\
\hline Clarias gabonensis Günther, 1867 & + & + & + & - \\
\hline Clarias gariepinus (Burchell, 1822) & - & - & + & - \\
\hline Clarias hilli Fowler, 1936 & + & + & + & + \\
\hline Clarias liocephalus Boulenger, 1898 & + & + & - & + \\
\hline Clarias pachynema Boulenger, 1903 & + & + & + & - \\
\hline Clarias sp. pachynema 'very long barbels' & - & + & + & + \\
\hline Clarias sp. pachynema 'long barbels and pectorals' & + & + & + & + \\
\hline Clarias platycephalus Boulenger, 1902 & + & + & + & + \\
\hline Heterobranchus longifilis Valenciennes, 1840 & + & + & - & $?$ \\
\hline \multicolumn{5}{|l|}{ CLAROTEIDAE (15) } \\
\hline Auchenoglanis occidentalis (Valenciennes, 1840) & + & + & + & + \\
\hline Chrysichthys brevibarbis (Boulenger 1899) & - & - & + & - \\
\hline Chrysichthys cranchii (Leach, 1818) & + & + & + & + \\
\hline Chrysichthys duttoni Boulenger, 1905 & - & + & + & + \\
\hline Chrysichthys habereri Steindachner, 1912 & + & + & + & + \\
\hline Chrysichthys longibarbis (Boulenger, 1899) & + & + & + & - \\
\hline Chrysichthys longipinnis (Boulenger, 1899) & + & + & + & - \\
\hline Chrysichthys ornatus Boulenger, 1902 & + & - & + & - \\
\hline Chrysichthys punctatus Boulenger, 1899 & + & + & - & - \\
\hline Chrysichthys thonneri Steindachner, 1912 & - & + & + & - \\
\hline
\end{tabular}


Table 1 cont.

\begin{tabular}{|c|c|c|c|c|}
\hline Species & Itimbiri & Aruwimi & $\begin{array}{l}\text { Lindi/ } \\
\text { Tshopo }\end{array}$ & Ituri \\
\hline Chrysichthys wagenaari Boulenger, 1899 & - & + & + & + \\
\hline Gephyroglanis congicus Boulenger, 1899 & - & + & - & + \\
\hline Parauchenoglanis balayi (Sauvage, 1879) & + & + & + & + \\
\hline Parauchenoglanis punctatus (Boulenger, 1902) & + & + & + & + \\
\hline Parauchenoglanis sp. 'Itimbiri' & $\mathrm{E}$ & - & - & - \\
\hline \multicolumn{5}{|l|}{ BAGRIDAE (1) } \\
\hline Bagrus ubangensis Boulenger, 1902 & + & + & - & + \\
\hline \multicolumn{5}{|l|}{ SCHILBEIDAE (8) } \\
\hline Parailia congica Boulenger, 1899 & + & + & + & - \\
\hline Pareutropius debauwi (Boulenger, 1900) & + & + & + & + \\
\hline Pareutropius mandevillei Poll, 1959 & - & - & + & - \\
\hline Schilbe grenfelli (Boulenger, 1900) & + & + & + & + \\
\hline Schilbe intermedius Rüppell, 1832 & + & + & + & - \\
\hline Schilbe laticeps (Boulenger, 1899) & + & + & - & - \\
\hline Schilbe marmoratus Boulenger, 1911 & + & + & + & - \\
\hline Schilbe yangambianus (Poll, 1954) & + & - & - & - \\
\hline \multicolumn{5}{|l|}{ NOTHOBRANCHIIDAE (13) } \\
\hline Aphyosemion cf. mustafiri Van der Zee et Sonnenberg, 2011 & - & + & - & + \\
\hline Aphyosemion castaneum Myers, 1924 & - & - & + & - \\
\hline Aphyosemion christyi (Boulenger, 1915) & $?$ & + & - & + \\
\hline Aphyosemion cf. elegans (Boulenger, 1899) & + & - & - & - \\
\hline Aphyosemion pseudoelegans Sonnenberg et Van der Zee, 2012 & - & + & - & - \\
\hline Aphyosemion schoutedeni (Boulenger, 1920) & + & + & - & - \\
\hline Aphyosemion sp. 'northeast' & + & + & - & - \\
\hline Epiplatys chevalieri (Pellegrin, 1913) & + & + & + & - \\
\hline Epiplatys dubiosi Poll, 1952 & - & + & - & - \\
\hline Epiplatys multifasciatus (Boulenger, 1913) & + & + & + & - \\
\hline Epiplatys singa (Boulenger, 1899) & - & + & - & - \\
\hline Fenerbahce cf. devosi Sonnenberg, Woeltjes et Van der Zee, 2011 & - & + & - & - \\
\hline Fenerbahce sp. 'Epulu' & - & $\mathrm{E}$ & - & $\mathrm{E}$ \\
\hline \multicolumn{5}{|l|}{ POECILIIDAE (6) } \\
\hline Aplocheilichthys huterauti (Boulenger, 1913) & + & - & - & - \\
\hline Hylopanchax silvestris (Poll et Lambert, 1958) & + & + & + & - \\
\hline Hypsopanchax platysternus (Nichols et Griscom, 1917) & - & + & + & + \\
\hline Pantanodon stuhlmanni (Ahl, 1924) & - & + & - & - \\
\hline Platypanchax cf. modestus (Pappenheim, 1914) & - & + & - & + \\
\hline Poropanchax myersi (Poll, 1952) & + & - & - & - \\
\hline \multicolumn{5}{|l|}{ MASTACEMBELIDAE (2) } \\
\hline Mastacembelus congicus Boulenger, 1896 & + & + & + & + \\
\hline Mastacembelus niger Sauvage, 1879 & + & + & - & - \\
\hline \multicolumn{5}{|l|}{ LATIDAE (1) } \\
\hline Lates niloticus (Linnaeus, 1758) & - & - & + & - \\
\hline \multicolumn{5}{|l|}{ CICHLIDAE (20) } \\
\hline Congochromis dimidiatus (Pellegrin, 1900) & + & - & + & - \\
\hline Congochromis squamiceps (Boulenger, 1902) & + & + & + & - \\
\hline Congolapia crassa (Pellegrin, 1903) & + & - & - & - \\
\hline Coptodon congica (Poll et Thys van den Audenaerde, 1960) & + & + & + & - \\
\hline Coptodon rendalli (Boulenger, 1896) & - & + & + & + \\
\hline Coptodon zilli (Gervais, 1848) & + & + & + & + \\
\hline 'Haplochromis' aeneocolor (Greenwood, 1973) & - & I & - & $\mathrm{I}$ \\
\hline Hemichromis elongatus (Guichenot, 1861) & + & + & + & + \\
\hline Hemichromis lifalili Loiselle, 1979 & + & + & + & - \\
\hline
\end{tabular}


Table 1 cont.

\begin{tabular}{|c|c|c|c|c|}
\hline Species & Itimbiri & Aruwimi & $\begin{array}{l}\text { Lindi/ } \\
\text { Tshopo }\end{array}$ & Ituri \\
\hline Heterochromis multidens (Pellegrin, 1900) & + & + & - & - \\
\hline Lamprologus mocquardi Pellegrin, 1903 & + & + & + & + \\
\hline Oreochromis leucostictus (Trewavas, 1933) & - & I & - & I \\
\hline Oreochromis macrochir (Boulenger, 1912) & - & $\mathrm{I}$ & - & $\mathrm{I}$ \\
\hline Oreochromis niloticus (Linnaeus, 1758) & $\mathrm{I}$ & $\mathrm{I}$ & - & I \\
\hline Orthochromis stormsi (Boulenger 1902) & - & - & + & - \\
\hline Pelmatochromis nigrofasciatus (Pellegrin, 1900) & + & - & - & - \\
\hline Pelmatochromis ocellifer Boulenger, 1899 & + & + & - & - \\
\hline Sarotherodon galilaeus (Linnaeus, 1758) & + & + & - & + \\
\hline Tylochromis lateralis (Boulenger, 1898) & + & + & + & + \\
\hline Tylochromis robertsi Stiassny, 1989 & + & + & - & + \\
\hline \multicolumn{5}{|l|}{ ELEOTRIDAE (2) } \\
\hline Kribia kribensis (Boulenger 1907) & + & - & - & - \\
\hline Kribia nana (Boulenger, 1901) & + & + & - & - \\
\hline \multicolumn{5}{|l|}{ ANABANTIDAE (11) } \\
\hline 'Ctenopoma' acutirostre (Pellegrin, 1899) & + & - & - & - \\
\hline 'Ctenopoma’ kingsleyae Günther, 1896 & + & + & - & - \\
\hline 'Ctenopoma' ocellatum Pellegrin, 1899 & + & + & - & - \\
\hline 'Ctenopoma' weeksii Boulenger, 1896 & + & - & - & - \\
\hline Ctenopoma nigropannosum Reichenow, 1875 & + & + & + & - \\
\hline Microctenopoma ansorgii (Boulenger, 1912) & - & + & - & - \\
\hline Microctenopoma congicum (Boulenger, 1887) & + & - & - & - \\
\hline Microctenopoma fasciolatum (Boulenger, 1899) & - & + & - & - \\
\hline Microctenopoma lineatum (Nichols, 1923) & + & - & - & - \\
\hline Microctenopoma nanum (Günther, 1896) & + & + & + & + \\
\hline Microctenopoma uelense Norris et Douglas, 1995 & + & + & - & + \\
\hline \multicolumn{5}{|l|}{ CHANNIDAE (2) } \\
\hline Parachanna insignis (Sauvage, 1884) & + & + & - & - \\
\hline Parachanna obscura (Günther, 1861) & + & - & + & - \\
\hline \multicolumn{5}{|l|}{ TETRAODONTIDAE (2) } \\
\hline Tetraodon mbu Boulenger, 1899 & + & + & + & + \\
\hline Tetraodon miurus Boulenger, 1902 & + & + & + & + \\
\hline \multicolumn{5}{|l|}{ PROTOPTERIDAE (1) } \\
\hline Protopterus dolloi Boulenger, 1900 & + & - & - & - \\
\hline
\end{tabular}

$+=$ present,$-=$ absent, $\mathrm{E}=$ endemic to the study region, $\mathrm{I}=$ introduced, $?=$ record not confirmed.

\section{RESULTS}

THE ICHTHYOFAUNA OF THE NORTH-EASTERN TRIBUTARIES

The identifications of the specimens from the five expeditions from 2009-2014, combined with the older collections at the RMCA and other institutions, resulted in a total of 320 species, belonging to 28 families and 114 genera: 232 in the Itimbiri, 246 in the Aruwimi, and 187 in the Lindi/Tshopo. These numbers include all species that were recognized in the region, including species that still need to be described (see below), but excluding the doubtful records (see above). An overview is given in Table 1. Presence or absence is indicated for the three tributaries studied. In addition, we provided separate entries for the Ituri to better illustrate its particular species composition. In all three tributaries, the Mormyridae was the most dominant family, representing respectively $17.7 \%, 17.9 \%$, and $19.3 \%$ of the species richness of the basins (Fig. 2). The next three dominant families, though not in the same order in each of the three systems, were the Distichodontidae, Alestidae, and Cyprinidae. Eleven out of the 320 species (3.4\%) are endemic to the region, eight of which from the Ituri (Table 1). The other three are endemic to the (lower reaches) of the Itimbiri. Four species have been introduced (Table 1), all of them belonging to the family Cichlidae and occurring in the Ituri River.

Several records of the collections of the RMCA, NHM, AMNH, and CU have been re-identified, resulting in the removal of some species from the species list of (a part of) the study area. These re-identifications have been listed in Table 2.

Among the 320 listed species, 10 are (probably) new to science and await formal description. These possible new species, and species that have an uncertain taxonomic status are discussed below, together with some other taxonomic issues. 


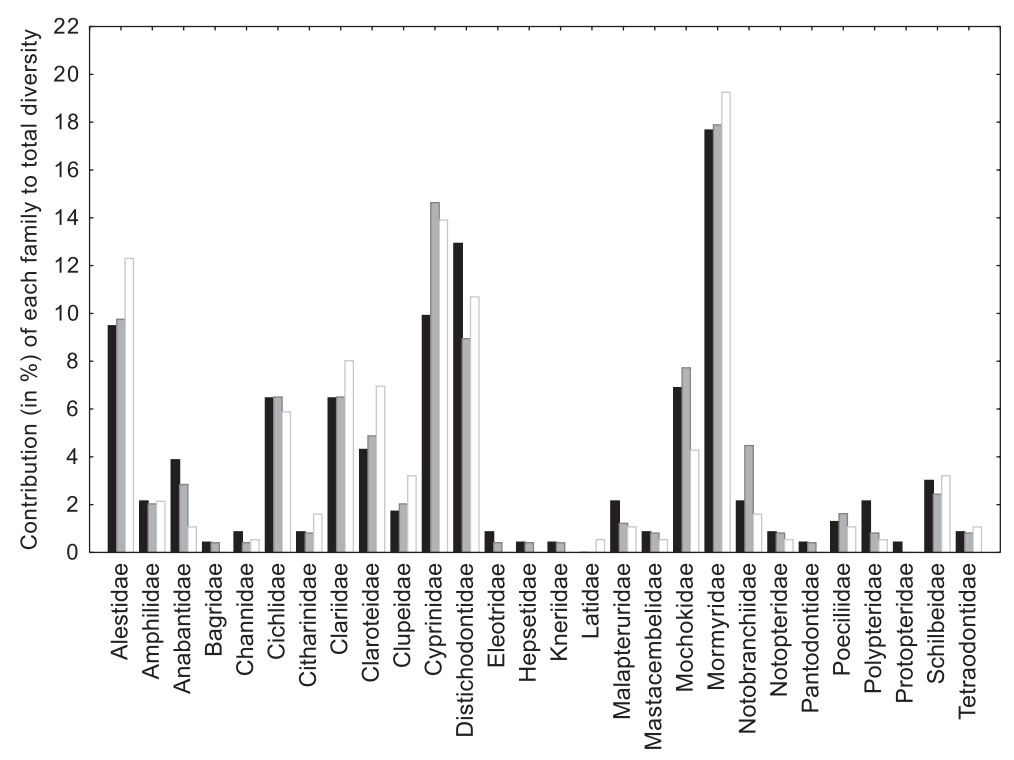

Fig. 2. Graph of the relative contributions of every family to the species richness in each basin explored: Itimbiri (black), Aruwimi (grey) and Lindi/Tshopo (white)

Mormyridae. The region is characterized by an extraordinary diversity of mormyrid taxa, 59 species in 13 genera (Table 1). One species awaits formal description: Marcusenius sp. 'ruiki' (Sullivan pers. comm.). This species resembles the most Marcusenius moorii (Günther, 1867) but differs from the latter mainly by its straighter head profile, higher number of anal fin rays, and lower dorsal fin/anal fin ratio.

One mormyrid specimen of the genus Petrocephalus could not be assigned to any of the valid Congolese species, but fitted the description of Petrocephalus simus Sauvage, 1879 described from the ichthyofaunal province Lower Guinea. Since $P$. simus most probably does not occur in the Congo basin (Lavoué et al. 2010, Lavoué and Sullivan 2014), the specimen is identified as Petrocephalus sp. 'simus Congo' (see also Decru et al. 2016a).

We experienced identification problems for Petrocephalus binotatus Pellegrin, 1924; Petrocephalus arnegardi Lavoué and Sullivan, 2014; and Petrocephalus boboto Lavoué et Sullivan, 2014. The latter two have recently been described from the Odzala National Park in the north-western part of the Congo basin (Lavoué and Sullivan 2014). However, when identifying, we were unable to assign the $P$. binotatus-like specimens from our study region with certainty to one of these three species. The specimens examined often displayed a combination of characteristics of $P$. binotatus and $P$. arnegardi. We encountered for example specimens with a large mouth like $P$. binotatus, but with only 21-22 branched dorsal rays, which is characteristic for $P$. arnegardi. Furthermore, morphological variation within $P$. boboto is currently unknown, because the only specimen is the holotype. Lavoué and Sullivan (2014) also described differences in electric organ discharges between the three species. However, since no live specimens were available to us, this identification technique could not be used. Therefore, in this study, the three species are grouped together and given the oldest name: P. binotatus.
Kneriidae. Kneriidae is a family of small fish species. Grasseichthys is considered a paedomorphic kneriid genus, due to its rather peculiar, larval-like appearance, very small size, and lack of skeletal ossification (Schelly 2007). To date, the genus is still monospecific, with Grasseichthys gabonensis Géry, 1964 as the only valid species, occurring in a few scattered localities in the Ivindo and Ogowe basins in Gabon, and in the Congo basin. The population in the Congo, however, represents a separate species that still needs to be described (Schelly 2007), and which is for now indicated as Grasseichthys sp. 'Congo'. Only one specimen of $G$. sp. 'Congo' has been recorded from the study area (RMCA collections), but the specimen was on loan and the identification could therefore not be checked. In addition, because the specimen is recorded from a doubtful locality, it is listed with a question mark in Table 1. The fact that few specimens of this putative new species are recorded (only one from the study region), could be due to sampling bias, as the species is very small and can virtually only be captured with small mesh size scoop-nets, a fishing technique which in our case has only been used when sampling the Ituri/Epulu region.

The only other species of the Kneriidae occurring in the study region is Parakneria cameronensis (Boulenger, 1909). Apart from the records from the study region, the species only occurs in Lower Guinea and the Dja River (Schelly 2007). Therefore, the occurrence of the species in the Aruwimi and Itimbiri would mean that the species has a very wide and scattered distribution, which seems rather unlikely. However, no morphological differences could be found between the specimens from the study region and P. cameronensis.

Cyprinidae. After the Mormyridae, the Cyprinidae was the most species-rich family in the area. Especially in the Aruwimi, the diversity of Cyprinidae was very high. This family is one of the most abundant freshwater fish families in Africa. Many cyprinid fish have a wide distribution and 
Table 2

Re-identifications of collection material, that resulted in the removal of some species from the species list of (a part of) the study area, and that are not already discussed in the text

\begin{tabular}{ll}
\hline Species & Re-identification \\
\hline Alestes liebrechtsii (from the Epulu) & Alestes macrophthalmus \\
Alestopetersius hilgendorfi (Boulenger, 1899) & Alestopetersius compressus \\
Alestopetersius leopoldianus (Boulenger, 1899) & Alestopetersius compressus \\
Brycinus macrolepidotus Valenciennes, 1850 & $\begin{array}{l}\text { Some B. grandisquamis, som } \\
\text { Brycinus sp. 'hepsetus' } \\
\text { Brachypetersius } \\
\text { Brachypetersius altus (from the Ituri) }\end{array}$ \\
$\begin{array}{ll}\text { Hydrocynus vittatus } \\
\text { Hydrocynus forskahlii (Cuvier, 1819) }\end{array}$ & \\
& Micralestes acutidens \\
Micralestes occidentalis (Günther, 1899) & Microctenopoma congicum \\
Fenerbahce formusus (Huber, 1979) & Fenerbahce sp. 'Epulu' \\
Hemichromis fasciatus Peters, 1857 & Hemichromis elongatus
\end{tabular}

Hemichromis bimaculatus Gill, 1862

Orthochromis polyacanthus (Boulenger, 1899)

Clariallabes longicauda (Boulenger, 1902)

Chrysichthys delhezi Boulenger, 1899

Chrysichthys macropterus (Boulenger, 1920)

Parauchenoglanis punctatus (from the Epulu)

Enteromius neumayeri (Fischer, 1884)

Labeo cylindricus (Peters, 1852)

Labeo luluae Fowler, 1930

Distichodus notospilus Günther, 1867

Nannocharax fasciatus Günther, 1867

Euchilichthys guentheri (Schilthuis, 1891)

Microsynodontis batesii Boulenger, 1903

Petrocephalus pallidomaculatus Bigorne et Paugy, 1990

Papyrocranus afer (Günther; 1868)

Hylopanchax stictopleuron (Fowler, 1949)

Polypterus palmas Ayres, 1850
Hemichromis lifallili

Orthochromis stormsi

Some Clariallabes uelensis, some Clariallabes laticeps Chrysichthys cranchii

One syntype is $C$. wagenaari, other is $C$. thonneri

Parauchenoglanis balayi

Enteromius sp.

Labeo annectens

Labeo parvus

Distichodus affinis

Nannocharax brevis

Euchilichthys royauxi

Microsynodontis christyi

Petrocephalus christyi

Papyrocranus congoensis

Hylopanchax silvestris

Polypterus polli
Remark

B. macrolepidotus is absent from the Congo basin (unpublished study)

H. forskahlii probably absent from the Congo basin (Goodier et al. 2011),

confirmed by a morphometric study

(Kisekelwa pers. observ.)

H. fasciatus probably absent from the Congo basin (Lamboj, pers. comm.; Bitja Nyom, pers. comm.); Awaiting further studies, all records are identified as $H$. elongatus

According to an unpublished revision of the genus Chrysichthys (Risch, 2003),

Specimen too damaged for correct ID, but is certainly not $E$. neumayeri

L. cylindricus probably absent from the Congo basin

$N$. fasciatus probably absent from the Congo basin (Jerep, pers. comm.)

Van der Zee et al. 2013

display geographical variation; revisions are scarce and often specimens could not be assigned with certainty to any of confined to small study areas. As such, many species of the valid species. The first group of specimens is listed as this family are difficult to identify, especially species of the Enteromius sp. ' $10 \mathrm{cps}$ ', which is most similar to Enteromius genera Enteromius and Labeo. From the former, 90 species are known to occur in the Congo River; many display only minor morphological differences and identification keys are lacking (Van Ginneken et al. 2017). Therefore, we depended mostly on the original descriptions and a compilation of the main characteristics made by EV. Some Enteromius atromaculatus (Nichols et Griscom, 1917) but has 10 caudal peduncle scales instead of 12. The second group is called Enteromius cf. brazzai, the specimens of which are more slender than Enteromius brazzai (Pellegrin, 1901), and have a different colour pattern. A DNA barcoding study (Decru et al. 2016a) also revealed that these specimens formed a separate 
genetic lineage from specimens identified as E. brazzai. The third group is called Enteromius cf. apleurogramma. Enteromius apleurogramma (Boulenger, 1911) was described from Lake Victoria and has not been reported from the Congo basin. However, we found three specimens within the RMCA collection identified as E. apleurogramma from the Ituri. We re-identified them as E. cf. apleurogramma. They indeed resemble mostly E. apleurogramma, but have 11 scales around the caudal peduncle (although in one specimen the caudal peduncle was damaged), and 5 to 6 perforated lateral line scales. In contrast, according to the original description, E. apleurogramma has 8 scales around the caudal peduncle, and no lateral line pores. However, the notion of E. apleurogramma has evolved since its original description. After the synonymization of several species with E. apleurogramma, the ranges of caudal peduncle scales and the number of perforated scales have expanded, now comprising the range of the Ituri population; hence our identification as E. cf. apleurogramma.

Enteromius pellegrini (Poll, 1939) was recorded from the Ituri basin (Lambert 1961, RMCA database), although it was described from Lake Kivu. Specimens from the Ituri identified as E. pellegrini have been compared with the type series of E. pellegrini. The Ituri specimens have a longer dorsal fin, but this could be due to damage, as the dorsal fins in the four types of E. pellegrini seem to be slightly broken. A recent study on some Enteromius species (Van Ginneken et al. 2017) revealed that in every river stretch in the Congo basin that was studied, morphologically very similar, but distinct species occurred. Therefore, we assume that the population in the Ituri River is not conspecific with E. pellegrini from Lake Kivu, although a further morphological and genetic revision will be necessary. The meristics and colour pattern of these Ituri specimens fit the description of Enteromius trinotatus (Fowler, 1936), described from the Ituri River near Saidi's village $\left(3^{\circ} 50^{\prime} \mathrm{N}, 27^{\circ} 19^{\prime} \mathrm{E}\right)$, the type series of which could not be sent on loan and examined. Hence, we consider the Ituri population previously identified as E. pellegrini to be conspecific with E. trinotatus (see below).

Additional problems exist within the genus Enteromius, since the study of Van Ginneken et al. (2017) revealed the existence of several cryptic species. Further examination and comparison with more specimens is needed, however, to delineate and describe the putative new species. Thus, although we are aware that our samples of Enteromius miolepis (Boulenger, 1902); Enteromius holotaenia (Boulenger, 1904); and E. atromaculatus are probably polyspecific, they are still presented here under one taxon name.

Labeobarbus mirabilis (Pappenheim, 1914) and Labeobarbus mawambi (Pappenheim, 1914) are both species described from the Ituri River at Mawambi, and only known from their holotype. As a morphological study indicates that L. mawambi is most probably a junior synonym of L. mirabilis (see Decru et al. in preparation*), only the latter name is mentioned in the species list.
For the genus Labeo, despite the two existing revisions (Reid 1985, Tshibwabwa 1997a, 1997b), many species delineations remain unclear, and identification problems persist (see also Decru et al. 2016a). A separate morphological study has been done on Labeo altivelis Peters, 1852 and Labeo weeksii Boulenger, 1909 revealing that both species are synonyms (Van Steenberge et al. 2017). Therefore, only the oldest available name, L. altivelis, is listed in the present paper.

Within the genus Leptocypris, several specimens from the study area resemble Leptocypris lujae (Boulenger, 1909), but lack the characteristic black dots on the flanks. Since we could not find any additional morphological differences, even after a more in-depth morphological examination, we identified them as L. lujae.

Hepsetidae. Recent revisions revealed the existence of six species instead of one species within this family (Decru et al. 2015). The specimens of the north-eastern tributaries belong to Hepsetus microlepis (Boulenger, 1901).

Alestidae. Two new alestid species were recently found in the study area. The first is Brycinus sp. 'hepsetus', which is mainly characterized by its prognathous upper jaw and high number of premaxillary teeth (Kone and Vreven pers. comm.). Initially, the specimens of this species were usually identified as Brycinus macrolepidotus Valenciennes, 1850, which was supposed to occur in West Africa, the Nile system, as well as the Congo basin. Since the population of the Congo turned out to represent a new species, $B$. macrolepidotus is now considered absent from the Congo basin (Kone and Vreven pers. comm.). The second new species in the region is Brycinus epuluensis Decru, Vreven, Sadio et Snoeks, 2016, an Epulu River endemic which has recently been described (Decru et al. 2016b). Taxonomic uncertainties still remain in Brycinus imberi (Peters, 1852), a widespread species that appears to be morphologically very variable. An on-going study at the RMCA revealed that the species is most probably polyspecific, but awaiting further results, the non-Epulu specimens are in our study still referred to as $B$. imberi.

Clariidae. Despite the fact that the genus Clarias has been revised by Teugels (1986), the correct identification of specimens remains challenging, and some taxonomic problems remain. In the presently reported study, two groups of specimens resembled Clarias pachynema Boulenger, 1903, but displayed some differences with this species. Therefore, they were listed as separate taxa which we designated as Clarias sp. 'pachynema very long barbels' and Clarias sp. 'pachynema long barbels and pectorals'. The first group differed from C. pachynema by a maxillary barbel length that ranged from 204.3\% HL to $323.2 \% \mathrm{HL}$ (vs. $106 \% \mathrm{HL}-188.1 \% \mathrm{HL}$ ); the other by a maxillary barbel length of $171.5 \%$ HL-235.6\% HL, a premaxillary tooth plate width of $26.3 \%$ HL$31.4 \%$ HL (vs. 19.6\% HL-27.6\% HL), and long pectoral fins $(12.6 \% \mathrm{SL}-15.4 \% \mathrm{SL}$ vs. $9.3 \% \mathrm{SL}-12.5 \% \mathrm{SL})$ and pelvic fins (8.9\% SL-11.7\% SL vs. $4.9 \%$ SL-8.7\% SL). A DNA barcoding study revealed these two groups indeed to be genetically distinct (Decru et al. 2016a). 
Additionally, the identification of specimens, according to Teugels (1986) belonging to Brevicephaloides, a subgenus of Clarias, is very difficult. Within the study region, Clarias camerunenis Lönnberg, 1895; Clarias dumerilii Steindachner, 1866; Clarias hilli Fowler, 1936; and Clarias liocephalus Boulenger, 1898 belong to this group. The distinction between the species is for a large part based on the development of lateral head bones, but several exceptions are known to this diagnostic character, which is moreover size dependent in some species (Teugels 1986). Other diagnostic characteristics to distinguish certain species have largely overlapping values.

Claroteidae. Two specimens were encountered in the Itimibiri that could not be assigned to any of the valid species within this family, and were designated as Parauchenoglanis sp. 'Itimbiri'. They resemble mostly Parauchenoglanis punctatus (Boulenger, 1902), but display a more mottled colour pattern, have a deeper caudal peduncle and longer barbels.

Nothobranchiidae. Several new species of this family have been described from the Congo basin the last couple of years, even from the north-eastern part (Sonnenberg et al. 2011, Van der Zee and Sonnenberg 2011, Sonnenberg and Van der Zee 2012). In our study region, two species, possibly new to science, were found: Fenerbahce sp. 'Epulu', and Aphyosemion sp. 'northeast'. Additionally, the identification of some specimens was uncertain (Van der Zee pers. comm.); in those cases the designation 'cf.' was used. An on-going study indicates that some of the specimens identified as Platypanchax cf. modestus (Pappenheim, 1914) and Hypsopanchax platysternus (Nichols et Griscom, 1917) may represent a new species (Bragança pers. comm.). Awaiting further conclusions, these specimens are still listed as Platypanchax cf. modestus or Hypsopanchax platysternus. According to Wildekamp (2004), H. platysternus also occurs in the lower reaches of the Itimbiri. However, we did not find any collection records of this species from that area, nor were collection numbers given by Wildekamp (2004). Also in Van der Zee et al. (2015; their fig. 1), H. platysternus was recorded from the lower reaches of the Itimbiri. However, this was based on an error (Van der Zee pers. comm.).

Cichlidae. This family gains a lot of attention of scientists, mainly because the species' flocks in the African Great Lakes provide a unique perspective to study speciation events. Riverine members of this family are less diverse. Yet, 20 species from 12 genera occurred in the study area, though four of them were most probably introduced in the wake of aquacultural activities.

'Haplochromis' is the most species-rich genus within the Cichlidae. The genus has been revised by Greenwood $(1979,1980)$, resulting in 25 lineages, which he considered distinct genera. This revision was however questioned and Hoogerhoud (1984) proposed to refer to 'Haplochromis' sensu lato as prior to Greenwood's revision, and to place the genus name between quotation marks, a practice we also have chosen to follow.
Even after the revision of the genus Tylochromis by Stiassny in 1989, identification problems remain for three species: Tylochromis lateralis (Boulenger, 1898), Tylochromis labrodon Regan, 1920; and Tylochromis variabilis Stiassny, 1989. According to the revision, T. labrodon can be distinguished from T. lateralis by a more robust lower pharyngeal jaw with mill-like, molariform teeth (vs. not robust and not mill-like), a fully ossified, closed post-temporal latero-sensory canal (vs. open), and shorter pectoral fins which rarely reach the level of the vent (vs. longer and usually reaching the level of the vent). However, when identifying our specimens, discriminating between the two species based on these characteristics was not obvious. Additionally, T. variabilis was described as a variable species (hence its name) without unambiguous morphological traits that characterise the species (Stiassny 1989). A morphological comparison of the three species (Musschoot pers. comm.) could not confirm the proposed diagnostic characters. Therefore, they are in the present work considered a single species, for which the oldest name T. lateralis is chosen.

Anabantidae. Within this family of labyrinth fishes, the genus Ctenopoma has proven to be paraphyletic (Norris 1995, Norris unpublished ${ }^{*}$ ), and should be restricted to only three species. The remaining species are transferred to either Microctenopoma (see Norris 1995), or to another, not yet described genus. This undescribed genus is referred to as 'Ctenopoma' (see Norris 2007), which has also been applied in the presently reported study.

\section{MICRALESTES SARDINA POLL, 1938 RELEGATED TO SYNONYMY WITH MICRALESTES HUMILIS BOULENGER, 1899}

Micralestes humilis is a widespread species that occurs throughout the whole Congo basin. Elsewhere, it is known from Lower Guinea (Cross, Ntem, and Ogowe rivers), the Niger, and Zambezi rivers and lakes Chad, Mweru, and Tanganyika (Paugy and Schaefer 2007). Micralestes sardina on the other hand is only known from the Upper Congo, from which it was also described (Kandulu, Luembe River, $12^{\circ} 46^{\prime} \mathrm{S}, 28^{\circ} 38^{\prime} \mathrm{E}$ ), and a few records from the Middle Congo near Kisangani (RMCA collection). Both species are only slightly different, based on some overlapping characteristics (Poll 1967): Micralestes humilis is said to have a larger head (3.4-3.8 vs. 3.75-4.1 times in the standard length) and fewer lateral line scales (24-27 vs. 26-28) than M. sardina. However, upon examining the types and 90 other specimens (see material examined below), no differences between the two species could be found, not even for the two diagnostic features according to Poll (1967). Specimens of both M. humilis and M. sardina had a range of 22-28 lateral line scales and highly overlapping values for head length (as \%SL). Head length was found to be negatively allometric. As the types of M. sardina are larger than the holotype of M. humilis (67.5-70.7 vs. 42.0 $\mathrm{mm}$ ), the larger head length in M. humilis according to Poll (1967) could be explained by this negative allometry. The number of lateral line scales of the holotype of M. humilis 
(27) fell into the range of the types of $M$. sardina (26-29). In addition to allometry, a possible wrong allocation of specimens to the species, could also have blurred the delineation of the two species. However, even when taking only specimens from the type region of both species into account, a very high overlap remained. As such, M. sardina is hereby considered a junior synonym of $M$. humilis.

Material examined. Micralestes humilis: MRAC 805, 1, holotype,42.0mmSL;DRC:Kutu.-MRAC118808-809,2,40.850.4 mm SL; DRC: Pool Malebo. —MRAC 57666-57667, 2, 43.2-51.4 mm SL; DRC: Kunungu. — MRAC 4783247833, 2, 41.8-44.5 mm SL; DRC: Flandria. MRAC 47848, 1, $58.1 \mathrm{~mm}$ SL; DRC: Flandria. MRAC 95-042-P-0171-0174, 1, 68.2 mm SL; DRC: Dja basin, Mpoo River near Dumo, next to Maleng V. MRAC 7907-7910, 4, 60.6-67.8 mm SL, DRC: Bosabangi. -MRAC 88-025-P-1153-1155, 3, 49.8-63.0 mm SL, DRC: Kinombwe creek, km 42 road KisanganiBafwasende. -MRAC 8094-8098, 5, 40.7-52.5 mm SL, DRC: Poko. — MRAC 74648-74651, 4, 50.4$60.5 \mathrm{~mm}$ SL; DRC: Kasai basin, Bushimaie River. MRAC 100609, 1, 62.2 mm SL; DRC: Lulua River, Katendi Falls. - MRAC 8165-8166, 2, 52.7-60.0 mm SL; Zambia: Lake Mweru. -MRAC 81312-81315, 1, 59.5 mm SL; Zambia: Lake Mweru, Kilwa.

Micralestes woosnami (Boulenger, 1907) (now considered a junior synonym of M. humilis): BMNH 1907.4.20.35, 1, lectotype, $61.8 \mathrm{~mm}$ SL; DRC: Aruwimi River.

Micralestes sardina Poll, 1938: MRAC 50040, 1, lectotype, $69.4 \mathrm{~mm}$ SL; DRC: Kandulu, near Sakania, tributary ofLuembeRiver.-MRAC50041,1,paralectotype, $70.7 \mathrm{~mm} \mathrm{SL}$; same data as lectotype. -MRAC 5004250051, 10, 63.3-70.6 mm SL; same data as lectotype. -MRAC 120868, 1, $72.5 \mathrm{~mm}$ SL; DRC: Yangambi, Congo basin. -MRAC 189348-349, 2, 47.2-48.4 mm SL; DRC: Wilia, Congo basin near Kisangani. MRAC 144807-812, 2, 41.4-44.5 mm SL; DRC: Kimilolo River, Katanga. -MRAC 124986-996, 2, 58.6-71.3 mm SL; DRC: Kiambi, Luvua River. -MRAC 120864-866, 2, 56.8-56.9 mm SL; DRC: Katanga, Luapula River, downstream of Kasenga. -MRAC 144729-735, 2, 55.3-69.5 mm SL; DRC: Kafubu River, Kiniama near Katanga bridge. -MRAC 144736-746, 2, 49.8-56.1 mm SL; DRC: Katanga, Kafubu River near Kitanda. MRAC 144776, 1, 35.2 mm SL; Katanga, River Kimilolo, sources. -MRAC 144778-792, 2, 31.2-32.3 mm SL; DRC: Katanga, Kamatété River. -MRAC 4483244833, 2, 63.5-66.2 mm SL; DRC: Kasenga, Luapula River. -MRAC 46685-46687, 2, 51.2-66.4 mm SL; DRC: Elisabethville. -MRAC 81422-81424, 2, 67.3-74.8 mm SL; DRC: Kafushia, road MambirimaKwele, Wiswila River, Sakania. -MRAC 73-24-P-24, 1, 74.2 mm SL; DRC: Kimbeshie, Luizi River, $100 \mathrm{~m}$ downstream of the Luizi-Luanza confluence. -MRAC 97093-P-0118, 1, $76.1 \mathrm{~mm}$ SL; Zambia: Nchelenge, Lake Mweru. -MRAC 97-093-P-0119-0120, 2, 68.3-73.4 mm SL; Zambia: Nchelenge, Lake Mweru. —MRAC 97-093P-0121-0122, 2, 58.8-62.0 mm SL; Zambia: Nchelenge, Lake Mweru.
ENTEROMIUS TRINOTATUS (FOWLER, 1936) AS A REPLACEMENT NAME FOR ENTEROMIUS TETRASPILUS (PFEFFER, 1896)

Enteromius tetraspilus was described, based on a single specimen from the Kavalli River, Upper Ituri $\left( \pm 1^{\circ} 24^{\prime} \mathrm{N}, \quad 30^{\circ} 15^{\prime} \mathrm{E}\right)$, by Pfeffer (1896) as Barbus tetraspilus, a name actually preoccupied by Barbus tetraspilus Günther, 1868. Although B. tetraspilus Günther, 1868 has been transferred to the genus Puntius (see Pethiyagoda et al. 2008), B. tetraspilus Pfeffer, 1896 (now in the genus Enteromius) remains an invalid name according to the International Code of Zoological Nomenclature (ICZN 1999: Article 57.2) as both taxa are primary homonyms. The holotype of E. tetraspilus, which is the only known specimen, is too damaged to be measured for morphometrical analysis to assess the taxonomic status of the species. Based on the original description, E. tetraspilus was compared with all Enteromius species from the Congo basin, using an unpublished list compiled by EV. In the combination of 31 lateral line scales, 4.5 scales above the lateral line, 7 branched dorsal fin rays and the presence of a series of round black spots on both lateral sides, E. tetraspilus resembles most E. pellegrini and E. trinotatus. However, all specimens of "E. pellegrini" from the Ituri were (re-) identified as E. trinotatus (see above). As the description of E. tetraspilus matches the one of E. trinotatus, and both species are described from the Ituri River, we regard them to be synonyms. Based on the principle of priority, E. trinotatus is a junior synonym of E. tetraspilus (ICZN 1999: Article 23.1). However, since E. tetraspilus is an invalid name, it has to be replaced by the name of the oldest available junior synonym (ICZN 1999: Article 60.1 and 60.2). As, at present, there is only one synonym known, E. trinotatus, this consequently becomes the replacement name for Enteromius tetraspilus (Pfeffer, 1896).

Material examined. Enteromius pellegrini: MNHN 19350080, 1, lectotype, 52.9 mm SL; DRC: Lake Kivu. MNHN 1935-0081-0082, 2, paralectotypes, 36.2-38.0 mm SL; same data as lectotype. - MNHN 1996-0265, 1, $43.3 \mathrm{~mm} \mathrm{SL}$; same data as lectotype. -MRAC 87514, 1, $83.8 \mathrm{~mm}$ SL; DRC: Ituri basin, camp Putnam, Epulu River and small affluents. -MRAC 172482-489, 7, 59.1-72.5 mm SL; DRC: Lubero, Biambwa, affluents of Biena River. -MRAC A9-029-P-881-883, 3, 40.7-50.8 mm SL; DRC: Ituri basin, Nepuse creek, small affluent of Epulu River near Epulu. -MRAC A9-029-P-884-889, 6, 54.7-62.2 mm SL; DRC: Ituri basin, Akokora, Koukou Falls, Epulu affluent. —MRAC A9-029-P-890, 1, 55.9 mm SL; DRC: Ituri basin, confluence Nduye and Biasa, downstream of the bridge near Nduye, Epulu affluent.

\section{EXAMINATION OF CONGO-ALBERTINE RIFT ICH- THYOFAUNAL SIMILARITIES}

After examination of the existing collections, 22 shared species were found between the north-eastern tributaries studied and the region of the Albertine Rift (Nile system). Taxonomic considerations concerning these species are listed below. 
Six species are reported from only a single capture locality in the region of the Albertine Rift, Mahagi (Ituri district, near Lake Albert, $02^{\circ} 18^{\prime} \mathrm{N}, 30^{\circ} 59^{\prime} \mathrm{E}$ ) and all caught during the same expedition by Schouteden in 1925: Brycinus imberi (Peters, 1852); Ctenopoma acutirostre Pellegrin, 1899; Clarias angolensis Steindachner, 1866; Clarias hilli; Enteromius atromaculatus; and Mastacembelus congicus Boulenger, 1896. We assume, in support of the suggestion by Norris (unpublished*) on the presence of C. acutirostre in the Nile basin, that there is a problem with the accurateness of the locality reported. As Mahagi is situated very close to the Congo-Nile divide, it is possible that, during the expedition of Schouteden, collections were made in parts of the Nile as well as of the Congo basin. As such, it is possible that the specimens were actually caught in the Congo system, and that the locality is indicating the nearest large city without further detail. We thus suspect that the occurrences of these six species in the region of the Albertine Rift are incorrect and based on an imprecise notation of the capture locality.

Four of the species are tilapiines that are commonly used in aquaculture and therefore regularly introduced, i.e., Coptodon zillii (Gervais, 1848); Oreochromis leucostictus (Trewavas, 1933); Oreochromis niloticus (Linnaeus, 1758); and Sarotherodon galilaeus (Linnaeus, 1758); only the former is native to the Congo basin. Indeed, fishfarming and the introduction of tilapiine fish have been reported from the Ituri region (Depasse 1956, Decru et al. 2017). These introduced species thus do not represent the region-specific ichthyofauna and are not considered evidence for historical ichthyofaunal exchange between the Congo system and region of the Albertine Rift. 'Haplochromis' aeneocolor is a cichlid species that is not used for aquaculture, but has probably been accidentally introduced in the Ituri. In the 1950s, several unregistered transports have taken place in the region, containing juvenile and small-sized tilapiine fish. It is not unlikely that small ' $H$ '. aeneocolor specimens have been mixed up with these tilapiine fish (Decru et al. 2017).

Auchenoglanis occidentalis (Valenciennes, 1840); Clarias gariepinus (Burchell, 1822); Heterobranchus longifilis Valenciennes, 1840; Lates niloticus (Linnaeus, 1758); Mormyrops anguilloides (Linnaeus, 1758); and Schilbe intermedius Rüppell, 1832 are species with a very wide distribution in Africa, beyond the Congo and Nile systems (Bigome 2003, Paugy 2003, Risch 2003, Teugels 1986, Teugels et al. 1991). These taxa should be examined further in order to get more insight into their evolutionary and biogeographic history, as well as the phylogenetic relations between different populations. Since such information is lacking at present, these five species are not considered as evidence for ichthyofaunal exchange between the Congo and Albertine Rift system in the Ituri region. Moreover, some widespread taxa may be polyspecific. Schilbe intermedius for example contains a very high degree of intraspecific variation in e.g., the length of the barbels, head profile, snout morphology, and the presence or absence of an adipose fin (De Vos
1995). An in-depth study of the different populations is needed and could reveal multiple species within the taxon (FishBase team RMCA and Geelhand 2016); hence the populations from the Congo and Nile systems may in fact represent separate species.

Platypanchax modestus is an aplocheiloid killifish that inhabits streams emptying into Lake Edward/George, the Semliki River, and the Upper Ituri System in northeastern DRC and western Uganda (Wildekamp 2004). However, preliminary morphological results indicate that the population in the Ituri in fact represents a new species (Bragança pers. comm.).

Micralestes acutidens (Peters, 1852) is another species reported from both river systems. Its presence in the Nile system is based on a single record from Kasenyi $\left(01^{\circ} 24^{\prime} \mathrm{N}, 30^{\circ} 26^{\prime} \mathrm{E}\right)$, on Lake Albert (MRAC 52851-52854). The identification could not be verified as the specimens could not be traced. Micralestes acutidens is often confused with Micralestes elongatus Daget, 1957 (see Paugy and Schaefer 2007), a species that does not occur in the Congo basin; hence a misidentification cannot be ruled out.

The African tigerfish, Hydrocynus vittatus Castelnau, 1861, has a wide distribution and occurs in the Congo basin as well as the Nile system. Recently, a cytochrome $b$ gene study (Goodier et al. 2011) suggested possible cryptic diversity in the species, with possibly five separate species in the Congo basin. Although no samples of $H$. vittatus from the Nile basin were included in their analyses, their results highlight the need of a taxonomic revision and the possibility of detecting additional species in areas outside their study region. Therefore, the population in our study region and the population(s) in the Nile system might represent separate species.

Clarias liocephalus is described from Lake Tanganyika and has, according to Teugels (1986), a distribution area that also includes lakes Victoria, Edward/George and Kivu, smaller lakes in Uganda and Rwanda, the Bangwelu-Mweru system, the lake Malawi system, the Kagera, Malagarazi, Ruzizi, and Tana rivers. The collections of the RMCA also harbour specimens from the Itimbiri and the Aruwimi/Ituri. Clarias liocephalus belongs to a group of species which are hard to identify (see above). In several species within this subgenus, the dermosphenotic and supraorbital (lateral bones on each side of the head) are not joined to each other and may be reduced. In some species, such as C. liocephalus, this character is size dependent, with the bones being separated in small specimens and joined in larger specimens. Moreover, exceptions have been noted for this species, with large specimens in which the joining never has taken place (Teugels 1986). Due to these identification difficulties, we could not confirm or reject with certainty whether the records from the Itimbiri and Aruwimi/Ituri (RMCA collections) were correctly identified as $C$. liocephalus.

Enteromius apleurogramma is described from Lake Victoria but three records from the Ituri were present in the RMCA collections. Re-examination of these specimens however revealed that they are most probably not conspecific with E. apleurogramma (see above). 
As the records of shared species are either based on questionable localities, widespread species, introduced species or species in need of taxonomic revision, they hardly represent evidence of a possible ichthyofaunal exchange through the former connection between the Congo and the Nile basin via the northern Albertine Rift area.

\section{DISCUSSION}

The contribution of five years of exploration. This study provides a first comprehensive list of the ichthyofauna in some important north-eastern tributaries of the Central Congo basin. However, several taxa still cause taxonomic problems. Before the onset of this study, a list of 300 species from the region could be compiled based on the RMCA records. After a re-examination of the existing collections and those of five recent expeditions, the total number is now 320. This does not mean that only 20 additional species were discovered during the process. Indeed, after re-identification of the collections, the total number of species decreased to 279 , which then added up to 320 after the recent expeditions. In the Itimbiri and Aruwimi, both the older RMCA collections and the material from recent expeditions contributed considerably to the total species diversity (Table 3 ). On the other hand, not many additional species were recently captured in the Lindi/Tshopo. This is most probably due to a low sampling effort, with only one small expedition done on a small river stretch that had already been explored before. The many additional species encountered after additional sampling efforts in the Itimbiri and Aruwimi confirm that the area was until recently still poorly sampled. Especially for the Aruwimi, the contribution of the recent expeditions is relatively high $(28.3 \%)$. This is mostly due to the two sampling expeditions (2009 and 2011) to the Ituri headwaters, a particularly poorly explored part of the Aruwimi. The Ituri has a very different species composition compared to other parts of the basin (see below). Many species present in the RMCA collections, were not found during the recent expeditions, especially in the Itimbiri and Lindi/Tshopo with respectively $47.8 \%$ and $58.9 \%$. This is not unexpected as the expeditions to the Itimbiri (2009 and 2010) and Lindi (2014) only covered small parts close to the main stream.

Table 3

Percentages of the species diversity covered by the older collections at the Royal Museum for Central Africa (old), the recent expeditions carried out between 2009 and 2014 (new), and both (common)

\begin{tabular}{lccc}
\hline \multicolumn{1}{c}{ River } & 'Old'\% & 'New'\% & Common\% \\
\hline Itimbiri & 47.8 & 19.6 & 32.6 \\
Aruwimi & 25.3 & 28.2 & 46.5 \\
Lindi/Tshopo & 58.9 & 4.0 & 37.1 \\
\hline
\end{tabular}

The fact that additional surveys led to many additional recorded species in the region indicates that possibly the presented inventory may not yet reflect the complete diversity in the region. Hence, the non-appearance in the list of some species from certain river stretches may as well be the result of a real absence as of insufficient sampling. However, our inventory is based on a relatively high degree of sampling compared to other areas in the basin and should cover a good representation of the actual diversity.

Endemics and introduced species. Only 11 of the documented species $(3.4 \%)$ are endemic to the study region (Table 1). Eight of these occur in the headwaters of the Aruwimi (Ituri/Epulu). The multiple waterfalls and rapids on these headwaters could form a barrier for fish dispersal and isolate the upstream sections. As such, they most probably contribute to this relatively high number of endemics, despite that the overall number of species is low in this area (see below). In the lower reaches of the Aruwimi, such barriers are absent. Indeed, the number of species in the lower reaches is much higher (see below), but mainly consist of species that also occur in the Congo main stream, and no endemics are recorded from this river stretch. Five of the endemics in the Ituri/ Epulu belong to the family Cyprinidae, which is also by far the most dominant family in this stretch. These include Labeobarbus humphri (Banister, 1976); Labeobarbus mirabilis; and Labeobarbus macroceps (Fowler, 1936). These are large species and strong swimmers that can negotiate fast-flowing waters. As such, they could be particularly adapted to zones with rapids (Welcomme and de Merona 1988), which are abundant in the area.

All introduced species are cichlid species found in the Ituri River (Table 1). Aquacultural activities and the presence of fish ponds have been reported from the Ituri region (Depasse 1956), and specifically the use of Oreochromis leucostictus; Oreochromis macrochir (Boulenger, 1912); and O. niloticus has been mentioned in the framework of the aquaculture project described by Depasse (1956). 'Haplochromis' aeneocolor is not a species that is used for aquaculture, but was probably accidentally introduced in the Ituri (see above).

Distribution patterns within the Aruwimi. Species richness and the relative representation of every family in the different sections of the Aruwimi basin (see material and methods) are presented in Table 4. Even though extensive sampling has been undertaken in the Epulu, only 39 species have been documented from this river. This low species richness could be the result of the Arabia Falls on the downstream part of this river, forming a physical barrier for fish dispersal. Similarly, the Ngoy Falls on the Ituri, just upstream of the Epulu/Ituri confluence (in the downstream section of A7; Fig. 1) seem to have influenced the species richness. Indeed all sections of the Aruwimi headwaters, upstream of the two waterfalls (A6-A9) yielded a similarly small number of species (Table 4). The species numbers in A2 to A4 (especially A2) were rather low compared to the other sections; this is most probably because very few records were available from these sections of the Aruwimi. From A1 and A5 on the other hand, many records were available, including those from the recent expeditions. In these regions, the 
number of species was much higher than that of the areas in between and of the headwaters. A gradual increase in species richness along an upstream-downstream gradient (Hawkes 1975, Matthews 1986) could also be a cause of the low species richness in the headwaters compared to the lower reaches. This is a well-known phenomenon for temperate and tropical stream fish communities, and has already been reported in several studies on African fishes (Kamdem Toham and Teugels 1998, Kouamélan et al. 2003, Ibanez et al. 2007). In the Aruwimi, this pattern was not that pronounced, which could be due to the fact that sampling has not been carried out in a standardized way, meaning that not every section is sampled equally intensive. The presence of the two barriers on the Epulu and the Ituri, could also explain the abrupt break in species richness between A5 and the more upstream sections, instead of a more gradual decrease that would be expected based on the upstream gradient alone. Not only in species richness, but also in species composition, differences exist throughout the Aruwimi basin (Table 4), with the main dissimilarities found between the headwaters (A6A9) and the lower reaches. In the lower reaches (A1), the Mormyridae was by far the most dominant family, covering $21.2 \%$ of the species richness. In the headwaters, above the falls (A7-A9), the Mormyridae covered only about $15 \%$ of the species richness, and even only $2.6 \%$ (one single species) in the Epulu (A6). The same trend, but to a somewhat lesser degree was noticeable in the Distichodontidae with a share of $10.6 \%$ of the species richness in the lower reaches, and only $5.1 \%$ to $5.8 \%$ in the Ituri upstream of the confluence with the Epulu, and even no recorded species from the Epulu. A reverse pattern was visible for the Cyprinidae. In the lower reaches, only $6.8 \%$ of the species were cyprinids, while these percentages increased greatly when moving up to the headwaters. In the Epulu, the Cyprinidae was clearly the most dominant family with 15 out of 39 species (38.5\%), and in the majority of upstream sections of the Ituri (A7A9) percentages varied between $28.2 \%$ and $34.6 \%$. For the Alestidae, also a well-represented family in terms of species diversity in the area studied (Fig. 2), no substantial differences were observed between various sections of the Aruwimi basin.

Mormyridae is the most dominant family in the Congo main stream (Poll 1963). As no geographical barriers exist in the lower reaches of the Aruwimi, fish species can easily disperse from the Congo main stream to this part of the tributary. As such, the ichthyofauna in the lower reaches greatly resembles the one of the Congo main stream, with also the Mormyridae being by far the most dominant family. Also, a high diversity of Cyprinidae has already been documented for the peripheral parts of the Congo basin in general (Matthes 1964), which is thus confirmed by our recorded species composition in the Ituri.

Noteworthy is the absence of the families Pantodontidae, Notopteridae, Eleotridae, Channidae, and Protopteridae in the headwaters (Table 1), though representatives of these families, e.g., Pantodon, Kribia, and Protopterus (P. dolloi) (Matthes 1964), commonly occur in the central part of the Congo basin. The fact that Eleotridae have not been encountered in the headwaters could also be due to sampling bias, as these very small species are not captured with gill nets or fykes, but only with scoop-nets (see above). However, scoop nets have been intensively used during the OWR 2009 expedition to the Ituri/Epulu. Therefore, the absence of this family in the Ituri is more likely to be real than the result of sampling bias. Interestingly, except for the Eleotridae, all these families that are absent from the Ituri, display morphological adaptations for air breathing. It is, however, difficult to link this observation to their absence in the Ituri. A possible explanation could be that these adaptations are less useful in the Ituri, where large oxygen-poor flooded areas, typical for the Cuvette Centrale, are lacking.

The presence of the two sets of waterfalls (the Arabia on the Epulu near its confluence with the Ituri, and the Ngoy just upstream of this confluence on the Ituri itself; Fig. 1), and the fact that the Ituri/Epulu is relatively well sampled offers an opportunity to evaluate whether the falls have a large influence on its species composition. Indeed, to some degree, the ichthyofauna in the Epulu has some specific characteristics not found in the other sections of the Ituri. First, three species seem to be endemic to the Epulu: Labeobarbus macroceps, Brycinus epuluensis, and Fenerbahce sp. 'Epulu'. In addition, nine families are absent from Epulu although they do occur in the rest of Ituri (e.g., Bagridae, Distichodontidae, Mastacembelidae, and Schilbeidae). The falls on the Ituri seem to have a somewhat lower impact on the species composition than the falls on the Epulu, with only five of the families occurring downstream that are absent upstream of these falls. In addition, two endemics occur in the upper sections of the Ituri, but they are species only known from their type specimens (Labeobarbus mirabilis and L. humphri). Despite the presence of these two waterfalls that can act as barriers, the ichthyofauna of the Epulu was generally similar to the upstream part of the Ituri, and more pronounced differences in species composition were noticed between the combined Ituri/Epulu headwaters and the lower reaches of the Aruwimi (discussed above).

In order to analyse differences and similarities between the different sections of the Aruwimi basin, a correspondence analysis was performed. A first analysis, including all sections of the Aruwimi (not illustrated), showed mainly that section A2 was largely separated from the rest. As only very few records were available from this part, sampling bias most probably caused these results. Therefore, section A2 was omitted from further analysis. On a scatterplot of the two dimensions of a subsequent analysis, the main differences are situated on the first axis (Fig. 3). Along this axis, three groups of river stretches can be distinguished:

- The lower reaches (A1) on the negative part of this axis;

- The middle sections (A3-A5) also on the negative part of this axis, but closer to the point 0.0 ;

- The headwaters of the Ituri (i.e., upstream of the confluence with the Epulu) and the Epulu (A6-A9), located on the positive part of this axis. 
Table 4

Species richness and relative representation of every family in the different parts (see text and Fig. 1) of the Aruwimi basin

\begin{tabular}{|c|c|c|c|c|c|c|c|c|c|c|c|c|c|c|c|c|c|c|}
\hline \multirow{2}{*}{ Family } & \multicolumn{2}{|c|}{ A1 } & \multicolumn{2}{|c|}{$\mathrm{A} 2$} & \multicolumn{2}{|c|}{ A3 } & \multicolumn{2}{|c|}{ A4 } & \multicolumn{2}{|c|}{ A5 } & \multicolumn{2}{|c|}{ A6 (Epulu) } & \multicolumn{2}{|c|}{ A7 } & \multicolumn{2}{|c|}{ A8 } & \multicolumn{2}{|c|}{ A9 } \\
\hline & $N$ & $\%$ & $N$ & $\%$ & $N$ & $\%$ & $N$ & $\%$ & $N$ & $\%$ & $N$ & $\%$ & $N$ & $\%$ & $N$ & $\%$ & $N$ & $\%$ \\
\hline Alestiidae & 16 & 12.1 & 2 & 20.0 & 8 & 8.3 & 6 & 13.6 & 16 & 11.9 & 3 & 7.7 & 5 & 9.6 & 6 & 15.4 & 5 & 13.5 \\
\hline Amphilidae & 0 & 0.0 & 0 & 0.0 & 4 & 4.2 & 0 & 0.0 & 1 & 0.7 & 2 & 5.1 & 0 & 0.0 & 0 & 0.0 & 1 & 2.7 \\
\hline Anabantidae & 5 & 3.8 & 0 & 0.0 & 3 & 3.1 & 2 & 4.5 & 2 & 1.5 & 1 & 2.6 & 1 & 1.9 & 1 & 2.6 & 0 & 0.0 \\
\hline Bagridae & 0 & 0.0 & 0 & 0.0 & 0 & 0.0 & 0 & 0.0 & 1 & 0.7 & 0 & 0.0 & 1 & 1.9 & 1 & 2.6 & 1 & 2.7 \\
\hline Channidae & 1 & 0.8 & 0 & 0.0 & 1 & 1.0 & 0 & 0.0 & 0 & 0.0 & 0 & 0.0 & 0 & 0.0 & 0 & 0.0 & 0 & 0.0 \\
\hline Cichlidae & 7 & 5.3 & 0 & 0.0 & 4 & 4.2 & 3 & 6.8 & 6 & 4.4 & 3 & 7.7 & 5 & 9.6 & 2 & 5.1 & 4 & 10.8 \\
\hline Citharinidae & 2 & 1.5 & 0 & 0.0 & 0 & 0.0 & 0 & 0.0 & 1 & 0.7 & 0 & 0.0 & 0 & 0.0 & 0 & 0.0 & 0 & 0.0 \\
\hline Clariidae & 9 & 6.8 & 3 & 30.0 & 5 & 5.2 & 8 & 18.2 & 6 & 4.4 & 6 & 15.4 & 3 & 5.8 & 3 & 7.7 & 2 & 5.4 \\
\hline Claroteidae & 9 & 6.8 & 0 & 0.0 & 3 & 3.1 & 1 & 2.3 & 7 & 5.2 & 1 & 2.6 & 1 & 1.9 & 1 & 2.6 & 1 & 2.7 \\
\hline Clupeidae & 3 & 2.3 & 0 & 0.0 & 1 & 1.0 & 1 & 2.3 & 4 & 3.0 & 0 & 0.0 & 0 & 0.0 & 0 & 0.0 & 0 & 0.0 \\
\hline Cyprinidae & 9 & 6.8 & 1 & 10.0 & 16 & 16.7 & 4 & 9.1 & 28 & 20.7 & 15 & 38.5 & 18 & 34.6 & 11 & 28.2 & 11 & 29.7 \\
\hline Distichodontidae & 14 & 10.6 & 0 & 0.0 & 15 & 15.6 & 8 & 18.2 & 13 & 9.6 & 0 & 0.0 & 3 & 5.8 & 2 & 5.1 & 2 & 5.4 \\
\hline Eleotridae & 1 & 0.8 & 0 & 0.0 & 0 & 0.0 & 0 & 0.0 & 0 & 0.0 & 0 & 0.0 & 0 & 0.0 & 0 & 0.0 & 0 & 0.0 \\
\hline Hepsetidae & 1 & 0.8 & 0 & 0.0 & 0 & 0.0 & 1 & 2.3 & 0 & 0.0 & 0 & 0.0 & 0 & 0.0 & 0 & 0.0 & 0 & 0.0 \\
\hline Kneriidae & 0 & 0.0 & 0 & 0.0 & 0 & 0.0 & 0 & 0.0 & 0 & 0.0 & 1 & 2.6 & 0 & 0.0 & 0 & 0.0 & 0 & 0.0 \\
\hline Latidae & 0 & 0.0 & 0 & 0.0 & 0 & 0.0 & 0 & 0.0 & 0 & 0.0 & 0 & 0.0 & 0 & 0.0 & 0 & 0.0 & 0 & 0.0 \\
\hline Malapteruridae & 2 & 1.5 & 0 & 0.0 & 1 & 1.0 & 0 & 0.0 & 1 & 0.7 & 0 & 0.0 & 0 & 0.0 & 0 & 0.0 & 0 & 0.0 \\
\hline Mastacembelidae & 1 & 0.8 & 0 & 0.0 & 1 & 1.0 & 1 & 2.3 & 1 & 0.7 & 0 & 0.0 & 1 & 1.9 & 1 & 2.6 & 1 & 2.7 \\
\hline Mochokidae & 7 & 5.3 & 0 & 0.0 & 10 & 10.4 & 3 & 6.8 & 10 & 7.4 & 2 & 5.1 & 2 & 3.8 & 2 & 5.1 & 1 & 2.7 \\
\hline Mormyridae & 28 & 21.2 & 0 & 0.0 & 16 & 16.7 & 1 & 2.3 & 31 & 23.0 & 1 & 2.6 & 9 & 17.3 & 6 & 15.4 & 5 & 13.5 \\
\hline Notobranchiidae & 5 & 3.8 & 3 & 30.0 & 2 & 2.1 & 4 & 9.1 & 2 & 1.5 & 3 & 7.7 & 0 & 0.0 & 0 & 0.0 & 1 & 2.7 \\
\hline Notopteridae & 2 & 1.5 & 0 & 0.0 & 1 & 1.0 & 0 & 0.0 & 0 & 0.0 & 0 & 0.0 & 0 & 0.0 & 0 & 0.0 & 0 & 0.0 \\
\hline Pantodontidae & 1 & 0.8 & 0 & 0.0 & 1 & 1.0 & 0 & 0.0 & 0 & 0.0 & 0 & 0.0 & 0 & 0.0 & 0 & 0.0 & 0 & 0.0 \\
\hline Poeciliidae & 1 & 0.8 & 1 & 10.0 & 0 & 0.0 & 0 & 0.0 & 0 & 0.0 & 1 & 2.6 & 2 & 3.8 & 2 & 5.1 & 1 & 2.7 \\
\hline Polypteridae & 1 & 0.8 & 0 & 0.0 & 0 & 0.0 & 0 & 0.0 & 1 & 0.7 & 0 & 0.0 & 0 & 0.0 & 0 & 0.0 & 0 & 0.0 \\
\hline Protopteridae & 0 & 0.0 & 0 & 0.0 & 0 & 0.0 & 0 & 0.0 & 0 & 0.0 & 0 & 0.0 & 0 & 0.0 & 0 & 0.0 & 0 & 0.0 \\
\hline Schilbeidae & 6 & 4.5 & 0 & 0.0 & 2 & 2.1 & 1 & 2.3 & 2 & 1.5 & 0 & 0.0 & 1 & 1.9 & 1 & 2.6 & 1 & 2.7 \\
\hline Tetraodontidae & 1 & 0.8 & 0 & 0.0 & 2 & 2.1 & 0 & 0.0 & 2 & 1.5 & 0 & 0.0 & 0 & 0.0 & 0 & 0.0 & 0 & 0.0 \\
\hline Total $N$ & 132 & & 10 & & 96 & & 44 & & 135 & & 39 & & 52 & & 39 & & 37 & \\
\hline
\end{tabular}

The Aruwimi basin has been divided into sections of about $130 \mathrm{~km}$, with A1 being closest to the main stream, and A9 the most upstream section; A5 up to A9, the upstream sections of the Aruwimi basin, are called the Ituri River; A5 is the section downstream of the confluence of the Epulu with the Ituri, A6 is the Epulu itself, and A7-A9 are sections of the Ituri River upstream of this confluence; $N=$ number of species; Total $N=$ total number of species.

As such, the different sections are structured along an upstream-downstream gradient, from the lower reaches up to the headwaters. On axis 2, sections A3-A5 are clearly separated from the remaining sections. This separation could be due to the fact that A3 and A4 (with the most positive values) are the most poorly sampled river sections in the dataset (apart from the excluded A2). However, section A5 is also located on the positive part of axis 2, while it has been intensively sampled.

The correspondence analysis confirms that the Epulu (A6) only slightly differs in species composition from the other sections of the Ituri River (A7-A9), upstream from the confluence Epulu/Ituri, which points to only a limited impact of the waterfalls on the Epulu. The most downstream section, of what is called the Ituri (A5), does not cluster with the other sections of the Ituri on axis 1. Instead, it is situated closer to the more downstream sections of the Aruwimi, which could be explained by the effect of the Arabia and Ngoy Falls (see above).

Environmental parameters could also play an important role in the fish distribution in the area. Data of online available GIS layers (Foley et al. 1996) indeed indicates differences in environmental conditions between headwaters and lower reaches of the Aruwimi. For example, in the headwaters, annual precipitation and mean water temperature is lower than the middle and lower sections (respectively about $1300 \mathrm{~mm}$ vs. $1700 \mathrm{~mm}$; and $17^{\circ} \mathrm{C}$ vs. $25^{\circ} \mathrm{C}$ ). Thus, in addition to the influence of physical 


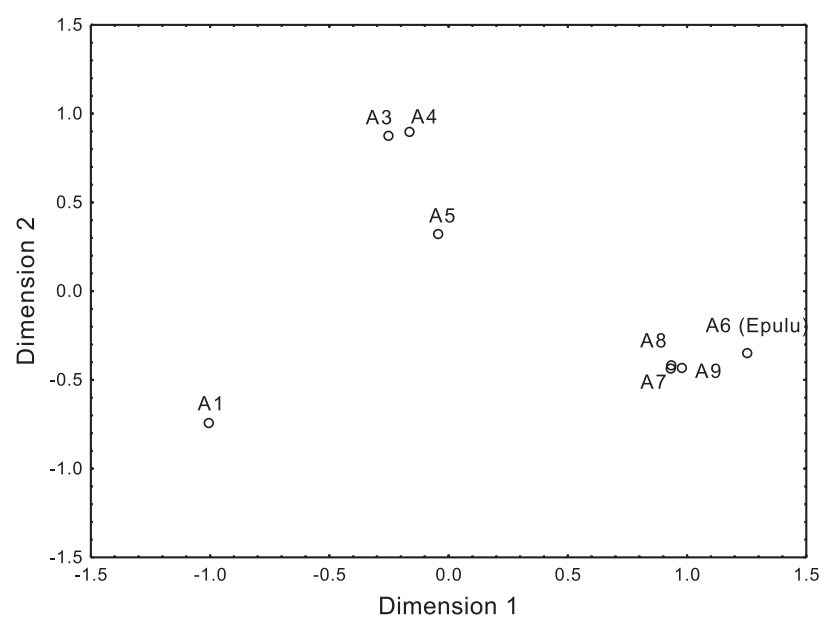

Fig. 3. Scatterplot of dimension 2 (19.87\% of inertia) against dimension 1 (28.06\% of inertia) of a correspondence analysis executed on a presence matrix (0-1) of recorded species in different parts of the Aruwimi basin; for delineation of the different parts, see Fig. 1

barriers, these differences in environmental conditions could also explain the differences in species composition between the headwaters and the lower reaches. The fact that the most upstream sections of the Ituri (including the Epulu) all seem to have similar environmental conditions, could also explain the similar ichthyofauna in the Epulu and the other sections of the headwaters. The dissimilarities between sections of a basin and the presence of endemics in smaller (isolated) river stretches (e.g., three in the Epulu River), is something to consider for conservational issues, as protected areas often only comprise a small part of river basins. As such, only the ichthyofauna of that specific part will fall under protective regulations. In the Aruwimi basin, the Okapi Wildlife Reserve comprises a part of the Ituri headwaters and a large part of the Epulu River. The location of this reserve is beneficial as the specific ichthyofauna of the headwaters is protected. Indeed, our results indicate that these headwaters have a different species composition from the lower reaches and harbour several endemics, while most species from the lower reaches also occur in the Congo main stream. However, in the more upstream part of the Ituri River, outside of the reserve, there are important mining activities (AW pers. comm.). These activities may have a severe negative impact on the fish species due to runoff of sediments, and also affect the fish populations in more downstream parts, including the parts of the basin that fall within the Okapi Wildlife Reserve.

\section{ACKNOWLEGDEMENTS}

We acknowledge the following organizations: the Stichting tot Bevordering van het Wetenschappelijk Onderzoek in Afrika, the Directorate-General for Development Cooperation and Humanitarian Aid, the Belgian Federal Science Policy Office (Belspo), de Nationale Loterij, and the Fonds Wetenschappelijk Onderzoek for funding the Congo 2009 and 2010, the OWR 2009, Ituri 2011, and Lindi/Tshopo 2014 expeditions. We also thank Prof. Akaibe Dudu (University of Kisangani) and the ichthyological team from the Centre de Surveillance de la Biodiversité (Kisangani) for great help in preparing and during the expeditions; and Miguël Parrent (RMCA) for managing the collections. We are grateful to Tuur Moelants (RMCA) for the collaboration in identifying the specimens; to Lora Van de Walle (University of Leuven), An-Katrien Cuypers (University of Leuven), and Laura Gajdzik (University of Liège) for the help in individual taxonomic case studies; to Fernando Jerep (Universidade Estadual de Londrina) for identifying the species of Nannocharax, to Jouke R. Van der Zee, Rainer Sonnenberg, and Pedro Bragança (Federal University of Rio de Janeiro) for identifying the killifish, and to John Sullivan for identifying some specimens from CU. We thank Ekaterina D. Vasil'eva (Zoological Museum, Moscow State University) for pointing out the problem of primary homonymy in Enteromius tetraspilus. We also thank John Friel (CU), Melany Stiassny (AMNH), Radford Arrindell (AMNH). James Maclaine (NHM), and Patrice Pruvost (MNHN) for providing the list of specimens within their institutions and the loan of specimens under their care. This study is part of a $\mathrm{PhD}$ scholarship to ED (Actie 2, 2012-2015) by Belspo.

\section{REFERENCES}

Abell R., Thieme M., Revenga C., Bryer M., Kottelat M., Bogutskaya N., Coad B., Mandrak N., Contreras Balderas S., Bussing W., Stiassny M.L.J., Skelton P., Allen G.R., Unmack P., Naseka A., Ng R., Sindorf N., Robertson J., Armijo E., Higgins J.V., Heibel T.J., Wikramanayake E., Olson D., López H.L., Reis R.E., Lundberg J.G., Sabaj M.H., Petry P.P. 2008. Freshwater ecoregions of the world: A new map of biogeographic units for freshwater biodiversity conservation. BioScience 58 (5): 403-414.

DOI: $10.1641 / \mathrm{b} 580507$

ICZN 1999. International code of zoological nomenclature. 4th edn. The International Trust for Zoological nomenclature 1999 c/o The National History Museum, London.

Banister K.E., Bailey R.G. 1979. Fishes collected by the Zaïre River Expedition, 1974-75. Zoological Journal of the Linnean Society 66 (3): 205-249. DOI: $10.1111 /$ j.1096-3642.1979.tb01909.x

Beadle L.C. 1981. The inland waters of tropical Africa. 2nd edn. Longman, London, UK.

Bigome R. 2003. Mormyridae. Pp. 155-222. In: Paugy D., Lévêque C., Teugels G.G. (eds.) The fresh and brackish water fishes of West Africa, Volume I. IRD, MNHN and MRAC, Paris and Tervuren.

Cahen L. 1954. Géologie du Congo Belge. VaillantCarmanne, Liège, Belgium.

Decru E., Moelants T., De Gelas K., Vreven E., Verheyen E., Snoeks J. 2016a. Taxonomic challenges in freshwater fishes: A mismatch between morphology and DNA barcoding in fish of the north-eastern part of the Congo basin. Molecular Ecology Resources 16 (1): 342-352. 
DOI: 10.1111/1755-0998.12445

Decru E., Snoeks J., Vreven E. 2015. A taxonomic evaluation of the Hepsetus from the Congo basin with the revalidation of $H$. microlepis (Teleostei: Hepsetidae). Ichthyological Exploration of Freshwaters 26 (3): 273-287.

Decru E., Vreven E., Sadio O., Snoeks J. 2016 b. Brycinus epuluensis, a new species from the Epulu River (Congo basin), Africa (Teleostei: Alestidae). Ichthyological Exploration of Freshwaters 27 (1): 49-60.

Decru E., Vreven E., Snoeks J. 2017. The occurrence of an eastern African haplochromine cichlid in the Ituri River (Aruwimi, Congo basin): Adaptive divergence in an introduced species? Hydrobiologia 791 (1): 209220.

DOI: $10.1007 / \mathrm{s} 10750-016-2857-9$

Depasse P. 1956. Monographie piscicole de la province Orientale. Description du milieu limnologique; programme er réalisations en matière de pêche et de pisciculture. Bulletin Agricole du Congo Belge 47 (4): $1-130$.

De Vos L. 1995. A systematic revision of the African Schilbeidae (Teleostei, Siluriformes): with an annotated bibliography. Annales du Musée Royal de 1'Afrique Centrale, Série in- $8^{\circ}$, Sciences Zoologique 271: $1-450$.

FishBase team RMCA, Geelhand D. 2016. Schilbe intermedius. The IUCN Red List of Threatened Species 2016: e.T181729A84245484. [Downloaded on 16 August 2017.]

DOI: 10.2305/IUCN.UK.2016-3.RLTS.T181729A84245484.en

Foley J.A., Prentice I.C., Ramankutty N., Levis S., Pollard P., Sitch S., Haxeltine A. 1996. An integrated biosphere model of land surface processes, terrestrial carbon balance, and vegetation dynamics. Global Biogeochemical Cycles 10 (4): 603-628.

DOI: $10.1029 / 96 \mathrm{~GB} 02692$

Froese R., Pauly D. (eds.) 2017. FishBase. [Version 06/2017] www.fishbase.org

Goodier S.A.M., Cotterill F.P.D., O'Ryan C., Skelton P.H., de Wit M.J. 2011. Cryptic diversity of African tigerfish (Genus Hydrocynus) reveals palaeogeographic signatures of linked Neogene geotectonic events. PLoS ONE 6 (12): e28775.

DOI: 10.1371 /journal.pone.0028775

Greenwood P.H. 1979. Towards a phyletic classification of the 'genus' Haplochromis (Pisces, Cichlidae) and related taxa. Part 1. Bulletin of the British Museum (Natural History) Zoology 35 (4): 265-322.

DOI: 10.5962/bhl.part.20455

Greenwood P.H. 1980. Towards a phyletic classification of the 'genus' Haplochromis (Pisces, Cichlidae) and related taxa. Part II; The species from lakes Victoria, Nabugabo, Edward, George and Kivu. Bulletin of the British Museum (Natural History) Zoology 39 (1): 1-101.

DOI: $10.5962 /$ bhl.part.13268
Hanssens M. 2009. A review of the Clarias species (Pisces; Siluriformes) from the Lower Congo and the Pool Malebo. Journal of Afrotropical Zoology 2009 (5): 27-40.

Hawkes H.A. 1975. River zonation and classification. Pp. 312-374. In: Whitton B.A. (ed.) River Ecology. University of California Press, Berkeley.

Hoogerhoud R.J.C. 1984. A taxonomic reconsideration of the Haplochromine genera Gaurochromis Greenwood, 1980 and Labrochromis Regan, 1920 (Pisces, Cichlidae). Netherlands Journal of Zoology 34 (4): 539-656.

DOI: $10.1163 / 002829684 x 00281$

Ibanez C., Oberdorff T., Teugels G., Mamononekene V., Lavoué S., Fermon Y., Paugy D., Toham A.K. 2007. Fish assemblages structure and function along environmental gradients in rivers of Gabon (Africa). Ecology of Freshwater Fish 16 (3): 315-334. DOI: $10.1111 / \mathrm{j} .1600-0633.2006 .00222 . \mathrm{x}$

Kamdem Toham A., Teugels G.G. 1998. Diversity patterns of fish assemblages in the Lower Ntem River Basin (Cameroon), with notes on potential effects of deforestation. Archiv für Hydrobiologie 141 (4): 421446.

DOI: 10.1127/archiv-hydrobiol/141/1998/421

Katuala P.G., Hart J.A., Hutterer R., Leirs H., Dudu A. 2005. Biodiversity and ecology of small mammals (rodents and shrews) of the "Réserve de Faune à Okapis", Democratic Republic of the Congo. Belgian Journal of Zoology 135 (Suppl.): 191-196.

Koenig R. 2008. Critical time for African rainforests. Science 320 (5882): 1439-1441.

DOI: $10.1126 /$ science.320.5882.1439

Kouamélan E.P., Teugels G.G., N'Douba V., Bi G.G., Koné T. 2003. Fish diversity and its relationships with environmental variables in a west African basin. Hydrobiologia 505 (1-3): 139-146.

DOI: $10.1023 / \mathrm{b}:$ hydr.0000007302.74296.84

Lambert J.G. 1961. Sur une petite collection de poissons de l'Ituri-Uélé. Revue de Zoologie et de Botanique Africaines 64 (3-4): 309-314.

Lavoué S., Sullivan J.P. 2014. Petrocephalus boboto and Petrocephalus arnegardi, two new species of African electric fish (Osteoglossomorpha, Mormyridae) from the Congo River basin. ZooKeys 400: 43-65. DOI: $10.3897 /$ zookeys.400.6743

Lavoué S., Sullivan J.P., Arnegard M.E. 2010. African weakly electric fishes of the genus Petrocephalus (Osteoglossomorpha: Mormyridae) of Odzala National Park, Republic of the Congo (Lékoli River, Congo River basin) with description of five new species. Zootaxa 2600: 1-52.

Lowenstein J.H., Osmundson T.W., Becker S., Hanner R., Stiassny M.L.J. 2011. Incorporating DNA barcodes into a multi-year inventory of the fishes of the hyperdiverse lower Congo River, with a multigene performance assessment of the genus Labeo as a case study. Mitochondrial DNA 21 (Supl. 1): 1-19. DOI: $10.3109 / 19401736.2010 .537748$ 
Manly B.F.J. 1994. Multivariate statistical methods. A primer. 2nd edn. Chapman and Hall, Boca Raton, FL, USA.

Matthes H. 1964. Les poissons du lac Tumba et de la région d'Ikela. Étude systématique et écologique. Annales du Musée Royal de l'Afrique Centrale, Série in- $8^{\circ}$, Sciences Zoologiques No.126: 1-204.

Matthews W.J. 1986. Fish faunal 'breaks' and stream order in the eastern and central United States. Environmental Biology of Fishes 17 (2): 81-92.

DOI: $10.1007 / \mathrm{bf} 00001739$

Monsembula Iyaba R.J.C., Liyandja T., Stiassny M.L.J. 2013. Fishes of the N'sele River (Pool Malebo, Congo basin, central Africa): A list of species collected in the main channel and affluent tributaries, Kinshasa Province, Democratic Republic of Congo. CheckList 9 (5): 941-956.

DOI: $10.15560 / 9.5 .941$

Norris S.M. 1995. Microctenopoma uelense and M. nigricans, a new genus and two new species of anabantid fishes from Africa. Ichthyological Explorations of Freshwaters 6 (4): 357-376.

Norris S.M. 2007. Anabantidae. Pp. 251-268. In: Stiassny M.L.J., Teugels G.G., Hopkins C.D. (eds.) Poissons d'eaux douces et saumâtres de basse Guinée, ouest de l'Afrique centrale. Fresh and brackish water fishes of Lower Guinea, West-Central Africa. Vol. 2. IRD and MNHN, Paris and RMCA, Tervuren.

Paugy D. 2003. Centropomidae. Pp. 451-453. In: Paugy D., Lévêque C., Teugels G.G. (eds.) The fresh and brackish water fishes of West Africa Vol. 2. IRD and MNHN, Paris and RMCA, Tervuren.

Paugy D., Schaefer S.A. 2007. Alestidae. Pp. 347411. In: Stiassny M.L.J, Teugels G.G., Hopkins C.D. (eds.) Poissons d'eaux douces et saumâtres de basse Guinée, ouest de l'Afrique centrale. Vol. I. IRD and MNHN, Paris and RMCA, Tervuren.

Pethiyagoda R., Silva A., Maduwage K., Meegaskumbura M. 2008. Puntius kelumi, a new species of cyprinid fish from Sri Lanka (Teleostei: Cyprinidae). Ichthyological Exploration of Freshwaters 19 (3): 201-214.

Pfeffer G.J. 1896. Die Thierwelt Ost-Afrikas und der Nachbergebiete. Lief. von Die Fische Ost-Afrikas 3: $1-72$.

Poll M. 1963. Zoogéographie ichthyologique du cours supérieur du Lualaba. Publication de l'Université de l'Etat à Elisabethville 6: 95-106.

Poll M. 1967. Révision des Characidae nains africains. Annales du Musée Royal de l'Afrique Centrale, Série in- $8^{\circ}$, Sciences Zoologiques 162: 1-158.

Reid G.M. 1985. A revision of African species of Labeo (Pisces: Cyprinidae) and a re-definition of the genus. Verlag von J. Cramer, Braunschweig, Germany.

Risch L.M. 2003. Claroteidae. Pp. 61-96. In: Paugy D., Lévêque C., Teugels G.G. (eds.) Faune des poissons d'eaux douces et saumâtres de l'Afrique de l'Ouest. The fresh and brackish water fishes of West Africa. Vol. 2. IRD, MNHN, Paris and MRAC, Tervuren.
Runge J. 2007. The Congo River, Central Africa. Pp. 293 309. In: Gupta, A. (ed.) Large rivers: geomorphology and management. John Wiley and Sons, Chichester, UK.

Sabaj Perez M.H. (ed.). 2014. Standard symbolic codes for institutional resource collections in herpetology and ichthyology: an Online Reference. Version 5.0 (22 September 2014). American Society of Ichthyologists and Herpetologists, Washington, DC, USA. http:// www.asih.org/

Schelly R.C. 2007. Kneriidae. Pp. 335-342. In: Stiassny M.L.J, Teugels G.G., Hopkins C.D. (eds.) Poissons d'eaux douces et saumâtres de basse Guinée, ouest de l'Afrique centrale. Fresh and brackish water fishes of Lower Guinea, West-Central Africa. Vol. 1. IRD and MNHN, Paris and RMCA, Tervuren.

Snoeks J., Harrison I.J., Stiassny M.L.J. 2011. The status and distribution of freshwater fishes. Pp. 4291. In: Darwall W., Smith K., Allen D., Holland R., Harrison I., Brooks E. (eds.) The diversity of life in African freshwaters: Underwater, under threat. An analysis of the status and distribution of freshwater species throughout mainland Africa. IUCN, Gland and Cambridge.

Sonnenberg R., Van der Zee J.R. 2012. Aphyosemion pseudoelegans (Cyprinodontiformes: Nothobranchiidae), a new killifish species from the Cuvette Centrale in the Congo Basin (Democratic Republic of Congo). Bonn Zoological Bulletin 61 (1): 3-12.

Sonnenberg R., Woeltjes T., Van der Zee J.R. 2011. Description of Fenerbahce devosi (Cyprinodontiformes: Nothobranchiidae), a new species of dwarf killifish from the eastern Congo Basin in the Democratic Republic of Congo. Zootaxa 2966: $1-12$.

Stiassny M.L.J. 1989. A taxonomic revision of the African genus Tylochromis (Labroidei, Cichlidae); with notes on the anatomy and relationships of the group. Annales du Musée Royal de l'Afrique Centrale, Série in- $8^{\circ}$, Sciences Zoologiques 258: 1-161.

Stiassny M.L.J., Brummett R.E., Harrison I.J., Monsembula R., Mamonekene V. 2011. The status and distribution of freshwater fishes of Central Africa. Pp. 27-47. In: Brooks E.G.E., Allen D.J., Darwall W.R.T. (eds.) The status and distribution of freshwater biodiversity in Central Africa. IUCN, Gland and Cambridge.

Teugels G.G. 1986. A systematic revision of the African species of the genus Clarias (Pisces; Clariidae). Annales du Musée Royal de l'Afrique Centrale, Série in- $8^{\circ}$, Sciences Zoologiques 247: 1-199.

Teugels G.G., Risch L., De Vos L., Thys Van den Audenaerde D.F.E. 1991. Generic review of the Africa bagrid catfish genera Auchenoglanis and Parauchenoglanis with description of a new genus. Journal of Natural History 25 (2): 499-517. DOI: $10.1080 / 00222939100770311$

Thieme M.L. Abell R., Stiassny M.L.J., Skelton P., Lehner B., Teugels G.G., Dinerstein E., Kamdem 
Toham A., Burgess N., Olson D. 2005. Freshwater ecoregions of Africa and Madagascar: A conservation assessment. Island Press, Washington DC, USA.

Tshibwabwa S.M. 1997a. Systématique des espèces africaines du genre Labeo (Teleostei, Cyprinidae) dans les régions ichtyogéographiques de Basse-Guinée et du Congo. I. Presses Universitaires de Namur, Namur, Belgium.

Tshibwabwa S.M. 1997b. Systématique des espèces africaines du genre Labeo (Teleostei, Cyprinidae) dans les régions ichtyogéographiques de Basse-Guinée et du Congo. II. Presses Universitaires de Namur, Namur, Belgium.

Van Damme D., Pickford M. 1999. The late Cenozoic Viviparidae (Mollusca, Gastropoda) of the Albertine Rift Valley (Uganda-Congo). Hydrobiologia 390 (13): 171-217.

DOI: $10.1023 / \mathrm{A}: 1003518218109$

Van Damme D., Van Bocxlaer B. 2009. Freshwater molluscs of the Nile Basin, past and present. Pp. 585629. In: Dumont H.J. (ed.) The Nile. Springer, the Netherlands.

Van der Zee J.R., Sonnenberg R. 2011. Aphyosemion musafirii (Cyprinodontiformes: Nothobranchiidae), a new species from the Tshopo Province in the
Democratic Republic of Congo, with some notes on the Aphyosemion of the Congo Basin. Bonn Zoological Bulletin 60 (1): 73-87.

Van Ginneken M., Decru E., Verheyen E., Snoeks J. 2017. Morphometry and DNA barcoding reveal cryptic diversity in the genus Enteromius (Cypriniformes: Cyprinidae) from the Congo basin, Africa. European Journal of Taxonomy No. 310: 1-32.

DOI: $10.5852 /$ ejt.2017.310

Van Steenberge M., Gajdzik L., Chilala A., Snoeks J., Vreven E. 2017. Don't judge a fish by its fins: Species delineation of Congolese Labeo (Cyprinidae). Zoologica Scripta 46 (3): 264-274.

DOI: $10.1111 /$ zsc. 12203

Van Steenberge M., Vreven E., Snoeks J. 2014. The fishes of the Upper Luapula area (Congo basin): a fauna of mixed origin. Ichthyological Exploration of Freshwaters 24 (4): 289-384.

Welcomme R.L., De Merona B. 1988. Fish communities of rivers-Peuplements ichtyologiques des rivières. Pp. 251-276. In: Lévêque C., Bruton M.N., Ssentongo G.W. (eds.) Biologie et écologie des poisons d'eau douce africains. ORSTOM, Paris, France.

Wildekamp R.H. 2004. A world of killies. Atlas of the oviparous cyprinodontiform fishes of the world. American Killifish Association, Houston TX, USA.

Received: 5 October 2016

Accepted: 30 June 2017

Published electronically: 30 September 2017 